Published in final edited form as:

ChemMedChem. 2019 March 05; 14(5): 545-560. doi:10.1002/cmdc.201800725.

\title{
Highly Selective and Potent Human $\beta$-Secretase 2 (BACE2) Inhibitors against Type 2 Diabetes: Design, Synthesis, X-ray Structure and Structure-Activity Relationship Studies
}

\author{
Arun K. Ghosh ${ }^{\mathrm{a}}$, Margherita Brindisi ${ }^{\mathrm{a}}$, Yu-Chen Yen ${ }^{\mathrm{b}}$, Emma K. Lendy ${ }^{\mathrm{b}}$, Satish Kovela ${ }^{\mathrm{a}}$, \\ Emilio Leal Cárdenas ${ }^{a}$, Bhavanam Sekhara Reddya ${ }^{a}$, Kalapala Venketeswara Rao ${ }^{a}$, Deborah \\ Downs $^{c}$, Xiangping Huang ${ }^{c}$, Jordan Tang ${ }^{c}$, and Andrew D. Mesecar ${ }^{b}$ \\ aDepartment of Chemistry and Department of Medicinal Chemistry and Molecular Pharmacology, \\ Purdue University, West Lafayette, IN 47907

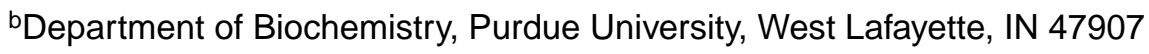 \\ 'Protein Studies Program, Oklahoma Medical Research Foundation, Department of Biochemistry \\ and Molecular Biology, University of Okalahoma Health Science Center, Oklahoma City, OK \\ 73104
}

\section{Abstract}

\begin{abstract}
We herein present the design, synthesis, and biological evaluation of potent and highly selective $\beta$ secretase 2 (memapsin 1, beta-site amyloid precursor protein cleaving enzyme 2 or BACE 2) inhibitors. BACE2 has been recognized as an exciting new target for type 2 diabetes. The X-ray structure of BACE1 bound to inhibitor $\mathbf{2 a}$ containing a hydroxyethylamine isostere was determined and based on this structure, a computational docking study was performed which led to inhibitor 2a-bound BACE2 models which were used to optimize the potency and selectivity of inhibitors. A systematic structure-activity relationship study led to identification of determinants of inhibitors' potency and selectivity towards the BACE2 enzyme. Inhibitors $2 \mathbf{d}\left(K_{\mathrm{i}}=0.031 \mathrm{nM}\right.$, selectivity over BACE1 $\approx 174,000$-fold) and $\mathbf{3 I}$ ( $K_{\mathrm{i}}=1.6 \mathrm{nM}$, selectivity over BACE1 over 500fold) displayed outstanding potency and selectivity. Inhibitor $\mathbf{3 l}$ is non-peptide in nature and may pave the way to the development of a new class of potent and selective BACE2 inhibitors with clinical potential.
\end{abstract}

\section{Design of Selective BACE2 Inhibitors}

Selective BACE2 inhibitors have been designed and synthesized as a potential new treatment for type 2 diabetes. Utilizing the X-ray structural studies with BACE1 along with computational docking approaches with BACE2, a series of potent and highly selective BACE2 inhibitors containing hydroxyethylamine isostere have been designed. The present investigation led to the identification of structural determinants and development for achieving potency and selectivity towards BACE2 enzyme. Inhibitor 31 exhibited excellent BACE2 potency and high selectivity over BACE1.

akghosh@purdue.edu.

Supporting information for this article is given via a link at the end of the document 


\section{Graphical Abstract}

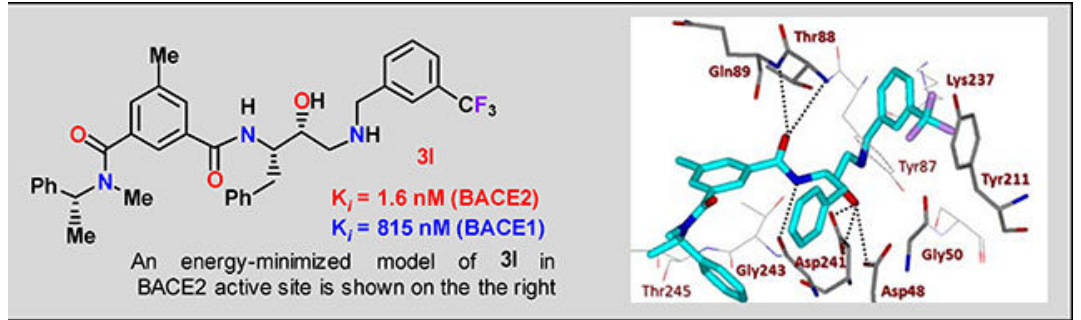

\section{Keywords}

BACE2 inhibitors; $\beta$-secretase 2; Tmem27; type 2 diabetes; structure-based design

\section{Introduction}

Type 2 diabetes mellitus is a major medical problem that seriously threatens human health worldwide, especially in developing countries. ${ }^{1}, 2$ International Diabetes Federation estimated that worldwide, there were 415 million adults between the age of 20-70 living with diabetes and 5 million deaths due to diabetes in $2015 .{ }^{3}$ The global burden for diabetes patient care exceeded over 673 billion dollars in $2015 .{ }^{3}$ The prevalence of diabetes has been increasing steadily, particularly in developing countries, with three quarters of patients being from low and middle income families. In some countries, the number of patients affected with diabetes is expected to increase even more rapidly due to the aging population and adding further to the healthcare burden., 5

Diabetes mellitus is a chronic, progressive metabolic disorder. It is characterized by hyperglycemia resulting from reduced insulin secretion from pancreatic beta-cells. ${ }^{6}$ The disease also originates from an increase in insulin demand associated with tissue insulin resistance. There is no cure for type 2 diabetes, however, treatment modalities include lifestyle modifications, treatment of obesity, administration of oral hypoglycemic agents and insulin sensitizers like metformin, a biguanide which reduces insulin resistance, a recommended first-line medication particularly for obese patients. Other effective antidiabetic medications include sulfonylureas, meglitinide, thiazolidinediones, sodiumglucose cotransporter 2 (SGLT2) inhibitors, and a-glucosidase inhibitors. ${ }^{7-9}$ Moreover, enhancing incretin action has been, in recent years, a widely utilized and effective approach for the treatment of type 2 diabetes. Strategies have been developed to circumvent dipeptidyl peptidase 4 (DPP-4) action, leading to the development of distinct glucagon-like peptide 1 (GLP-1) receptor agonists with longer half-lives (such as exenatide) as well as compounds blocking DPP-4 action and leading to increased endogenous GLP-1 levels (eg. sitagliptin). ${ }^{10}$ Despite these currently available options for lowering blood glucose, there are severe liabilities associated with these existing antidiabetic drugs, especially related to cardiovascular complications. ${ }^{11,12}$ Although examples of recent drugs with reduced risk of cardiovascular death have been reported (eg. the SGLT2 inhibitor empagliflozin), ${ }^{13}$ new therapies based upon innovative mechanisms are still urgently needed to address improvement of treatment and current unmet needs. 
A recent study demonstrated that inhibition of BACE2 in insulin-resistant mice resulted in an increase of beta-cell mass and improvement of insulin levels in mice. ${ }^{14}$ Importantly, another recent study has shown that BACE2 suppression promotes beta-cell survival and function in a model of type 2 diabetes induced by human islet amyloid polypeptide overexpression. ${ }^{15}$ Tmem 27 (collectrin) is a type 1 transmembrane protein and its over expression in pancreatic beta-cells leads to cellular proliferation, increased cell mass and increased insulin production. The excess Tmem 27 in beta-cells is regulated by BACE2 cleavage of Tmem27, resulting in the release of the Tmem 27 ectodomain outside the cell. ${ }^{16,17}$ These studies suggested that BACE2 inhibitors may have the potential for novel treatments of type 2 diabetes. ${ }^{18}$

BACE2 (memapsin 1) is a type 1 membrane-bound aspartic acid protease that belongs to the pepsin family. ${ }^{19}$ It is a close homologue of BACE1 which is highly expressed in the brain. 20,21 BACE2 is expressed in the alpha-cells of pancreatic islets and it is found in other peripheral tissues, the colon and kidney. ${ }^{22}$ It has been demonstrated that BACE2 inhibition results in beta-cell survival through a potential substrate, islet amyloid polypeptide (IAPP). Overexpression of IAPP leads to defects in glucose tolerance. ${ }^{23}$ BACE2 also cleaves plasma membrane protein Tmem 27 and regulates beta-cell mass and function. ${ }^{14}$ Taken together, BACE2 inhibition is potentially a viable new path for the treatment of diabetes. ${ }^{11,14,15}$ However, BACE2 inhibitors may need to be selective for a number of reasons. First of all, its closest homologue, BACE1, has a distinct physiological function in down-regulating brain neuronal function by cleaving APP and overproducing $\beta$-amyloid peptide $(A \beta)$ in the brain. 24 While BACE1 has been mechanistically an exciting target for possible treatment of Alzheimer's disease, BACE1 gene deletion resulted in behavioral abnormalities in mice. ${ }^{25}$ Furthermore, BACE1 is involved in the formation of myelin sheath in central and peripheral nerves. ${ }^{26,27}$ BACE1 may also have other important protein substrates. ${ }^{26,28}$

Diabetes is a chronic disease and for effective chronic treatment, any off-target toxicities need to be minimized, as collective toxicity burden over time could be severe. Therefore, development of selective BACE2 inhibitors over cathepsin D is also critically important. Cathepsin D is abundant in cells and it plays an important role in protein catabolism. ${ }^{29,30} \mathrm{In}$ addition, it has an important role in retinal function of the eyes. ${ }^{31,32}$ The majority of current BACE1 inhibitors lack selectivity and as a result, clinical toxicity has become a major issue. Thus far, there have been few selective BACE1 inhibitors that have been taken through clinical development. ${ }^{33,34}$ For the development of BACE2 inhibitor drugs for diabetes, inhibitor selectivity is critically important and there are only a few limited reports of BACE2 inhibitors with marginal selectivity. ${ }^{14,35}$ We recently reported our preliminary work on the design and synthesis of selective BACE2 inhibitors based upon transition-state isosteres. ${ }^{36}$ We have now expanded structure-activity relationship studies, determined a high-resolution X-ray structure of a potent and selective inhibitor complexed with BACE1 and created a structural model of inhibitor and BACE2 active site interactions. We herein report the full account of our studies detailing the design, synthesis, biological evaluation, X-ray crystallography and computational docking studies leading to potent and selective BACE2 inhibitors. 


\section{Results and Discussion}

In our preliminary efforts towards the design of potent and selective BACE2 inhibitors, we focused our inhibitor design based upon hydroxyethylamine isosteres as these dipeptide mimics are inherent to several FDA approved HIV-1 protease inhibitor drugs. ${ }^{37,38}$ Our starting point for the design of selective BACE2 inhibitors is compound $\mathbf{1}$ (Figure 1, $K_{\mathrm{i}}=1.8$ $\mathrm{nM}, \mathrm{BACE} 1$ ) which was designed by us as a potent BACE1 inhibitor. ${ }^{39}$ This inhibitor exhibits many drug-like properties including low toxicity and lipophilicity. Inhibitor $\mathbf{1}$ is quite potent against BACE1, but it also displayed inhibition towards BACE2 with a $K_{\mathrm{i}}$ value of $137 \mathrm{nM}$ which is 76 -fold less potent than BACE1 ${ }^{40} K_{\mathrm{i}}$ values for these compounds and all other compounds described herein were determined from kinetic data determined under tight-binding inhibition conditions and using the Morrison equation as described previously. 36

We next determined a high-resolution X-ray structure of inhibitor 1-bound BACE1 complex. ${ }^{39}$ The X-ray structure provided critical ligand-binding site interactions in the BACE1 active site as shown in Figure 2A. We have made a number of attempts to crystallize inhibitor $\mathbf{1}$ in complex with BACE2 but so far we have been unable to grow crystals suitable for structural studies. In the absence of an X-ray structure of a compound 1-bound BACE2 complex, we performed computational docking to create a model of inhibitor 1 bound in the BACE2 active site. The model was constructed using the available low-resolution X-ray structure of an inhibitor-bound BACE2 complex. ${ }^{41,42}$ The resulting model of inhibitor $\mathbf{1}$ bound in the active site of BACE2 is shown in Figure 2B. Our analysis of a compound 1-bound BACE2 computational model and the X-ray structure of 1-bound BACE1, suggested that certain BACE2 active site residues can be specifically targeted in order to achieve potency and selectivity (e.g. Gly50 and Thr88). Also, we hypothesized that the incorporation of polar substituents on the prime side would reduce BACE1 activity thus leading to more potent and selective BACE2 inhibitors. In particular, we observed that the methoxybenzyl moiety in inhibitor 1 is mostly engaged in non-polar interactions with residues in the hydrophobic S1'S2' subsites of BACE1. Therefore, replacement of the methoxybenzyl group with polar functionalities could improve selectivity towards BACE2. We therefore sought to simultaneously insert alcohol and amide polar functionalities by replacing the methoxybenzyl group with an allothreonine isobutylamide and other derivatives. ${ }^{36}$ Thus, replacement of the P1'-methoxybenzylamine of inhibitor $\mathbf{1}$ with an allothreonine derivative resulted in inhibitor 2a. Further structural modification led to the very potent and selective inhibitors $\mathbf{2 d}$ and $\mathbf{3 1}$.

\section{Chemistry}

Our synthesis of BACE2 inhibitors $\mathbf{2} \mathbf{f}-\mathbf{j}$ is shown in Scheme 1. Various isophthalamide derivatives $\mathbf{4 a}-\mathbf{7} \mathbf{b}$ were prepared using previously described procedures. ${ }^{43-46}$ For the synthesis of allothreonine isobutylamide derivatives, the Boc group of known ${ }^{43}$ isobutylamide derivatives 8a,b was deprotected in the presence of trifluoroacetic acid (TFA) in $\mathrm{CH}_{2} \mathrm{Cl}_{2}$ at $0{ }^{\circ} \mathrm{C}$ to $23{ }^{\circ} \mathrm{C}$ for $1 \mathrm{~h}$. Reaction of the resulting free amine with commercially available tert-butyl ((S)-1-((S)-oxiran-2-yl)-2-phenylethyl) carbamate 9 in 2-propanol heated at $80{ }^{\circ} \mathrm{C}$ for $18 \mathrm{~h}$, provided the corresponding epoxide open product. Exposure of the 
resulting Boc derivative to TFA in $\mathrm{CH}_{2} \mathrm{Cl}_{2}$ afforded amine derivatives 10a,b. Coupling of acids 5a,b and $\mathbf{6 a}, \mathbf{b}$ with amines 10a,b using EDCI and HOBt in the presence of $N, N$ diisopropylethylamine (DIPEA) in $\mathrm{CH}_{2} \mathrm{Cl}_{2}$ at $23{ }^{\circ} \mathrm{C}$ led to compounds $\mathbf{2 f}-\mathbf{j}$ with yields ranging from $39 \%$ to $78 \%$.

The synthesis of aminoalcohol derivatives containing the substituted aromatic rings is shown in Scheme 2. Commercially available aldehydes 11a,b were subjected to Wittig reaction with the appropriate alkyl triphenylphosphonium bromide leading to the corresponding olefins as $E / Z$ mixture. Isomerization of the olefin mixture in the presence of bis(acetonitrile)dichloropalladium(II) resulted in the $E$-olefins 12a-c in nearly quantitative yields. ${ }^{47}$ Asymmetric dihydroxylation of olefins 12a-c with AD-mix-a provided stereochemically defined diols 13a-c. These diols were converted into the corresponding diastereoisomeric mixtures (1:1) of cyclic sulfites 14a-c by treatment with thionyl chloride in the presence of triethylamine. ${ }^{48}$ Treatment of sulfites 14a-c with sodium azide in DMF at $80^{\circ} \mathrm{C}$, afforded azidoalcohols $\mathbf{1 5 a}-\mathbf{c}$ in excellent yields.

Catalytic hydrogenation of these azides in the presence of di-t-butyldicarbonate provided the Boc-protected aminoalcohols. Exposure of these Boc-derivatives to TFA in $\mathrm{CH}_{2} \mathrm{Cl}_{2}$ at $0{ }^{\circ} \mathrm{C}$ to $23{ }^{\circ} \mathrm{C}$ for $1 \mathrm{~h}$ furnished free aminoalcohols $\mathbf{1 6 a}-\mathbf{c} .49$

The synthesis of BACE2 inhibitors 3a-h (Table 2) with varying substituents on the aromatic rings and on the side chain is shown in Scheme 3. Opening of epoxide 9 carried on with amine derivatives 16a-c in isopropanol at $80{ }^{\circ} \mathrm{C}$ afforded aminoalcohol derivatives 17a-c. Deprotection of Boc-group by exposure to TFA followed by coupling of the resulting amines with the suitable carboxylic acids $\mathbf{4 a - d ^ { 3 6 }}$ using EDCI and HOBt in the presence of DIPEA led to final compounds $\mathbf{3 a}-\mathbf{h}$ (Table 2).

The syntheses of BACE2 inhibitors 3i-n (Table 3) with variation of P3 and P2'-ligands of inhibitor $\mathbf{1}$ is shown in Scheme 4. Opening of epoxide $\mathbf{9}$ with various benzyl amine derivatives provided amines $\mathbf{1 8 a}, \mathbf{b} .{ }^{39,50}$ These amines were coupled with acids $\mathbf{4 a}, \mathbf{4 b},{ }^{36} \mathbf{7 a}$ or $\mathbf{7 b},{ }^{51}$ using EDCI and HOBt in the presence of DIPEA to provide the final compounds $3 \mathbf{i}$ $\mathbf{n}$ (Table 3). Inhibitor 20 was synthesized starting from acetophenone derivative $\mathbf{1 9}$ following reported procedures. ${ }^{35}$

The synthesis of inhibitor 3o with a substituted oxazole derivative as the P3-ligand is shown in Scheme 5. Alkylation of commercially available oxazole $\mathbf{2 1}$ with methyl iodide in the presence of sec-butillithium and TMEDA led to alkylated derivative 22. Deprotection of the Boc group by exposure to TFA followed by coupling of the resulting amine with acid $\mathbf{2 3}$ in the presence of EDCI, HOBt and DIPEA furnished the amide derivative. Hydrolysis of ester with aqueous $\mathrm{LiOH}$ led to acid derivative $\mathbf{2 4}$. Coupling of acid $\mathbf{2 4}$ with amine $\mathbf{1 8 b}$, provided final inhibitor 30 in $48 \%$ yield.

\section{Structure-Activity Relationships}

At the outset, we replaced the methoxybenzylamine P1'-ligand of inhibitor $\mathbf{1}$ with an allothreonine isobutyl amide group. The resulting inhibitor 2a showed improvement of 
BACE2 potency with a $K_{\mathrm{i}}$ value of $14.6 \mathrm{nM}$ and demonstrated nearly 3-fold selectivity over BACE1. We next determined the X-ray structure of inhibitor 2a-bound BACE1 and created an active site model of 2a-bound to BACE2. The X-ray structure of 2a in complex with BACE1 is shown in Figure 3 and the computational model of 2a bound to the BACE2 active site is shown in Figure 4. We gained critical molecular insights on specific active site interactions that could improve potency and selectivity against the BACE2 enzyme. In particular, from the model of compound $\mathbf{2 a}$ bound to the BACE2 enzyme, it appeared that the $\mathrm{P} 2$ amide $\mathrm{NH}$ and the sulfonamide group on the P2-isophthalamide were not involved in significant polar interactions, in contrast to interactions of $\mathbf{2 a}$ in BACE1 active site. Based on this speculation, we first assessed compound $\mathbf{2 b}$ as the amide $\mathrm{N}$-methylated counterpart of compound 2a. The resulting inhibitor $\mathbf{2 b}$ displayed reduction of BACE2 potency, but improved selectivity over BACE1 $\left(K_{\mathrm{i}}=80 \mathrm{nM}\right.$ for BACE2 and $K_{\mathrm{i}}=1812 \mathrm{nM}$ for BACE1). ${ }^{36}$ We then designed compound $\mathbf{2 c}$ in which the sulfonamide moiety of $\mathbf{2 a}$ was replaced by a methyl group (Compound $2 \mathrm{c}$ displayed a BACE1 $K_{\mathrm{i}}$ value of $731 \mathrm{nM}$ and a BACE2 $K_{\mathrm{i}}$ value of $183 \mathrm{nM}$ ). Our analysis of binding properties of inhibitor $\mathbf{2} \mathbf{c}$ with respect to the model of compound 2a within the BACE2 active site (Figure 4) suggested that a larger P1' alkyl chain replacing the methyl group of allothreonine could result more effective in establishing van der Waals interactions with the surrounding hydrophobic residues. ${ }^{36} \mathrm{We}$ also planned to alkylate the amide $\mathrm{NH}$ and remove the $\mathrm{P} 2$-sulfonamide functionality. This prompted us to design compounds $\mathbf{2 d}$ and $\mathbf{2 e}$ (Table 1), which differ by the presence of an additional methyl on the isophthalic moiety benzene ring. Both compounds displayed excellent inhibitory activity on BACE2 $\left(K_{\mathrm{i}}=0.031 \mathrm{nM}\right.$ for $\mathbf{2 d}$ and $K_{\mathrm{i}}=0.038 \mathrm{nM}$ for $\left.2 \mathbf{e}\right)$ with inhibitor $\mathbf{2 d}$ showing outstanding selectivity over BACE1 (174,000 fold). ${ }^{36}$ To date, the only other relevant work on the design of selective BACE2 inhibitors is related to a patent which reported a series of 2-aminodihydro[1,3]-thiazines, as exemplified by inhibitor $\mathbf{2 0}$ (Scheme 4). ${ }^{33}$

Based on the high potency of 2a against the purified BACE2 enzyme, we next investigated whether inhibitor $2 \mathbf{a}$ could prevent processing of Tmem 27 in the pancreatic beta-cell line MIN6. ${ }^{52,53}$ Tmem27 behaves like a canonical BACE $1 / 2$ substrate, being subjected to subsequent intramembrane cleavage by the $\gamma$-secretase complex. This was confirmed by incubation of MIN6 cells with increasing concentrations of $\gamma$-secretase inhibitor $N$-[ $N$ - (3,5difluorophenacetyl)-L-alanyl]- $S$-phenylglycine $t$-butyl ester (DAPT) which led to the stabilization of a $22 \mathrm{kDa}$ C-terminal fragment (CTF) in the cell lysate. ${ }^{14}$ We tested our inhibitor 2a following the protocol employed by Esterhazy. ${ }^{14}$ Accordingly, the C-terminal fragment of Tmem27 was preserved from degradation in the presence of DAPT as shown in lane 1 (Figure 5). Without the treatment of DAPT, most of the CTF of Tmem27 was degraded as shown in lane 5. Hence, DAPT was added in the cellular assay for studying the in cellulo potency of potent inhibitors. For these studies, MIN6 cells were grown in the presence of various inhibitors, lysed and subjected to Western blot using a monoclonal antibody vs. Tmem $27 \mathrm{C}$-terminal region. The results are shown in Figure $5 .{ }^{14}$ As can be seen, the $22-\mathrm{kDa}$ C-terminal fragment of Tmem 27 was formed only in small extent in the presence of $0.4 \mu \mathrm{M}$ of inhibitor $\mathbf{2 a}$ (less than $5 \%$, lane 3). Then, in the presence of $0.9 \mu \mathrm{M}$ inhibitor 2a, the processing of Tmem 27 was completely abolished as shown in lane 4 . We 
used inhibitor 20, also known as compound J (BACE2 $K_{\mathrm{i}}=6 \mathrm{nM}$; BACE1 $K_{\mathrm{i}}=18 \mathrm{nM}$ ) as a positive control and the results are shown in lane $2 .{ }^{14}$

With the assumption that BACE2 processes its protein substrate PMEL in endosomes ${ }^{54}$ these results indicated that inhibitor 2a penetrated MIN6 cells and blocked the processing of Tmem 27 by BACE2. We now have greatly extended our structure-activity relationships and have further investigated determinants of inhibitors' potency and selectivity towards BACE2 through the design, synthesis and biological evaluation of a series of new inhibitors, namely $\mathbf{2 f - j}$ and 3a-o. First of all, we synthesised a focused subset of derivatives (compounds $\mathbf{2 f}-\mathbf{j}$, Table 1) in search of an effective P2-P3 ligand. Accordingly, we incorporated the isophthalamide terminal nitrogen in a substituted pyrrolidyl moiety (compounds $\mathbf{2 f , g}$ ) and replaced the $\mathrm{P} 2$ benzylamine portion with an isosteric thiazolylamine moiety (compounds $\mathbf{2 h}-\mathbf{j}$ ). We speculated that suitable heterocyclic moieties and their substituents could form favorable hydrogen bonds with backbone atoms as well as stronger van der Waals interactions in the active site of BACE2. In particular, we selected a 3-(R)-2(methoxymethyl)pyrrolidinylisophtalamide and a ((4-methylthiazol-2-yl)methyl)isophthalamide moiety in combination with a methyl or a longer propyl chain at the P1' alkylamide portion. In compounds $\mathbf{2 f}, \mathbf{g}$ bearing a 3- $((R)-2-$ (methoxymethyl)pyrrolidinylisophtalamide moiety, the insertion of a P1' propyl chain and a methyl group on 5-position of the isophthalamide benzene ring led to a significant increase of BACE1 and BACE2 activity. Accordingly, inhibitor $\mathbf{2 g}$ with a propyl P1'-side chain and a 3-methyl group on the P2-isophthalamide ligand led to improvement of both BACE1 and BACE2 inhibitory activity. However, inhibitor $2 \mathrm{~g}$ is more potent against BACE1 $\left(K_{\mathrm{i}}=6.6\right.$ $\mathrm{nM})$ than BACE2 $\left(K_{\mathrm{i}}=27.9 \mathrm{nM}\right)$. Compound $\mathbf{2 h}$ with a ((4-methylthiazol-2yl)methyl)isophthalamide moiety as the P3-ligand showed a BACE2 $K_{\mathrm{i}}$ of $97 \mathrm{nM}$ and displayed 2-fold selectivity over BACE1. Inhibitor $\mathbf{2 i}$ with a longer P1' alkyl chain in combination with no substitution on the isophthalamide phenyl ring showed improvement of BACE1 and BACE2 potency. Compound $\mathbf{2} \mathbf{j}$ with a methyl group on the isophthalamide group, displayed comparable BACE1 and BACE2 activity, however, no improvement of selectivity over BACE1 was observed.

Based on our structural insights, we then examined a small series on inhibitors combining the $((R)-1-1$ phenylethyl) isophthalamide as the P2-P3 ligand and a P1' ligand containing a reduced peptide character. Thus, we incorporated a stereochemically defined aminoalcohol moiety as a convenient handle to insert an alkyl chain of variable length similar to inhibitors 2d and 2e coupled with a substituted phenyl ring in place of isobutylamide. Beyond improving hydrophobic interactions, such an aryl moiety could also serve to mimic the P2' isobutylamide interaction with a suitably positioned polar group. Accordingly, we synthesized compounds 3a-h (Table 2). In general, this set of compounds showed decreased affinity towards BACE2 compared to their terminal isobutylamide counterparts such as inhibitors 2d and 2e. Inhibitor 3a, containing a 3-sulfonamide group on the isophthalic moiety displayed higher affinity towards the BACE1 enzyme $\left(K_{\mathrm{i}}=205 \mathrm{nM}\right.$ for BACE1 and $K_{\mathrm{i}}=731 \mathrm{nM}$ for BACE2). The amide $N$-methylation in inhibitor $\mathbf{3 b}$ led to higher affinity for BACE2 with slight improvement of potency and selectivity toward BACE2 over BACE1 $\left(K_{\mathrm{i}}\right.$ $=4852 \mathrm{nM}$ for BACE 1 and $K_{\mathrm{i}}=479 \mathrm{nM}$ for BACE2). 
The removal of the sulfonamide functionality on the isophthalamide phenyl ring (compounds 3c and 3d), did not improve potency but did increase BACE2 selectivity (54fold for compound $\mathbf{3 c}$ and 34 -fold for compound $\mathbf{3 d}$ ). In agreement with the previous series of compounds, a longer P1' alkyl chain had a beneficial effect for BACE2 inhibitory activity. Compound 3f, bearing a methyl substituent on the isophthalic phenyl ring and a terminal (1R,2S)-1-amino-1-(3-methoxyphenyl)pentan-2-ol displayed BACE2 inhibitory potency with a $K_{\mathrm{i}}$ value of $141 \mathrm{nM}$. Interestingly, compound 3e without a methyl group on the isophthalamide group, showed a more marked selectivity on BACE2 over BACE1 (159-fold for 3e and 62-fold for $\mathbf{3 f}$ ). The removal of the 3-methoxy substituent from the P1'-ligand led to compound 3g. However, this compound displayed a significant drop in BACE2 inhibitory activity. Similarly, removal of the 3-methoxy group from the P1'-ligand of inhibitor $\mathbf{3 f}$ resulted in compound $3 \mathbf{h}$ which also showed reduction of BACE2 $K_{\mathrm{i}}$ value of $905 \mathrm{nM}$ over 3f $\left(K_{\mathrm{i}}\right.$ value of $\left.141 \mathrm{nM}\right)$. These results indicated that the 3-methoxy substituent on the phenyl ring moiety may be involved in significant interactions in the active site.

Bearing in mind the data on prime and non-prime site preferences, we investigated a series of compounds (3i-o, Table 3) where we removed the 3-sulfonamide functionality from the P2 isophthalamide ligand and $\mathrm{N}$-methylated the amide $\mathrm{NH}$ of our initial lead inhibitor $\mathbf{1}$. Compound 3i with a 3-methoxylbenzylamine moiety as the P1'-ligand improved BACE2 potency with a $K_{\mathrm{i}}$ value of $39.4 \mathrm{nM}$. This compound showed over 52-fold selectivity for BACE2. Incorporation of a 3-methyl group on the isophthalamide group resulted in inhibitor 3j which showed nearly 3 -fold improvement of BACE2 $K_{\mathrm{i}}$. Also, it showed slight improvement of BACE2 selectivity (nearly 60-fold). Replacement of the 3-methoxy group on the P1'-ligand with a lipophilic 3-trifluoromethyl group resulted in inhibitor $3 \mathbf{k}$. This inhibitor (3k) displayed slight improvement of BACE2 activity ( $\mathrm{K}_{i}$ value of $\left.35.7 \mathrm{nM}\right)$. However, compound $\mathbf{3 k}$ showed reduction of BACE2 selectivity compared to inhibitor $\mathbf{3 i}$ (50-fold for 3i versus 37-fold for 3k). Interestingly, incorporation of a 3-methyl group on the P2-isophthalamide group of inhibitor $\mathbf{3 k}$ resulted in a very potent and selective inhibitor $\mathbf{3 1}$. Inhibitor $3 \mathrm{l}$ exhibited a BACE2 $K_{\mathrm{i}}$ value of $1.6 \mathrm{nM}$. Furthermore, inhibitor $\mathbf{3 l}$ showed over 500 -fold selectivity for BACE2. The combination of a P2 ((4-methyloxazol-2yl)methyl)isophthalamide derivative and a P1'3-methoxybenzylamino moiety provided compound $\mathbf{3 m}$. This inhibitor showed a dramatic loss of BACE2 potency but very potent BACE1 activity (3m, $K_{\mathrm{i}}=69 \mathrm{nM}$ for BACE1 and $K_{\mathrm{i}}=7.3 \mu \mathrm{M}$ for BACE2) with selectivity over 100-fold against BACE2.

Compound 3n, with a methyl substituent on the isophthalamide ring, further improved BACE1 activity with a $\mathrm{K}_{i}$ of $25 \mathrm{nM}$ and a selectivity $>75$-fold against BACE2. Based on the efficacy of the a-methyl group on the benzylisophthalamide moiety, we sought to explore the outcome of an a-methyl functionality on the oxazole-based inhibitors. Accordingly, compound 30 was synthesized as a mixture of diastereomers (1:1) on the methyl bearing center on the oxazolylmethyl group. This compound exhibited comparable BACE1 and BACE2 activity with no appreciable selectivity.

To obtain insight into the molecular binding properties responsible for potency and selectivity of inhibitors $\mathbf{2 d}$ and $\mathbf{3 l}$, we created energy-minimized active models for these 
inhibitors as shown in Figure 6A and 7A. The resulting models were selected based upon the $\mathrm{X}$-ray structure of the protein-ligand complex of BACE2 (Figure 6B and 7B). Figure 6B depicts an overlay of the inhibitor $\mathbf{2 d}$ model and the $\mathrm{X}$-ray crystal structure of a known hydroxyethylamine transition state inhibitor in the BACE2 active site. Inhibitor $\mathbf{2 d}$ shows a similar binding orientation as the hydroxyethylamine transition state inhibitor in the crystal structure (also applied to $\mathbf{3 l}$ in Figure 7B). The detailed docking procedures are shown in the supporting information. As can be seen in Figure 6A, inhibitor 2d makes extensive contacts in the $\mathrm{S}^{\prime}{ }^{\prime}$ and $\mathrm{S}^{\prime}{ }^{\prime}$ subsites. The $\mathrm{P} 1^{\prime}-\mathrm{NH}$ is within proximity to form hydrogen bonds with the Gly50 backbone $\mathrm{NH}$. The $\mathrm{P}^{2}{ }^{\prime}$-carbonyl as well as $\mathrm{P} 2^{\prime}-\mathrm{NH}$ are also within proximity to form hydrogen bonds with Thr88 backbone $\mathrm{NH}$ and side chain hydroxyl groups, respectively. Furthermore, the $\mathrm{P} 3{ }^{\prime}$-hydroxyl group is oriented toward Tyr211 hydroxyl group to form a hydrogen bond. The $(S)$-propyl group occupies a hydrophobic pocket surrounding Lys86, Ile239, and Tyr211. The P2 carboxamide carbonyl functionality is within proximity to form a hydrogen bond with Gln89 and the amide $\mathrm{NH}$ is also within hydrogen bonding distance with Thr244 side chain hydroxyl group. The P3-phenylmethyl group forms extensive hydrophobic interactions with Trp131, Thr245, and Phe125. Overall, the number of polar interactions of $\mathrm{P} 2$ and $\mathrm{P} 3$-ligands are significantly less compared to inhibitor 2a interactions with the BACE1 active site. The major difference between inhibitors $\mathbf{2 d}$ and $\mathbf{3 I}$ is that the inhibitor $\mathbf{3 l}$ contains a 3-trifluoromethylbenzyl group as the P2'-ligand in place of (2S,3S)-2-amino-3-hydroxy- $N$-isobutylhexanamide group as the P2-P3 ligand for $\mathbf{2 d}$. The P2'-ligand appears to make extensive hydrophobic interactions in the S2'-subsite. The interactions of $\mathrm{P} 2$ and $\mathrm{P} 3$-ligands are similar to inhibitor $\mathbf{2 d}$. The combination of active site interactions of inhibitors $\mathbf{2 d}$ and $\mathbf{3 l}$ with BACE2 may be responsible for their high BACE2 potency and selectivity.

\section{Conclusions}

Selective BACE2 inhibitors represent a potentially new treatment for type 2 diabetes. We present here the design, synthesis, and evaluation of a series of potent and highly selective BACE2 inhibitors. We have utilized the X-ray structural studies with BACE1 along with computational docking approaches with BACE2 to optimize the potency and selectivity. Furthermore, we have carried out an extensive SAR analysis to investigate determinants of inhibitors' potency and selectivity towards BACE2 enzyme using inhibitors $\mathbf{1}$ and $\mathbf{2 a}$ as the starting points. We have shown that inhibitor 2a blocked the processing of Tmem27 in the pancreatic beta-cell line MIN6. The X-ray structure of 2a-BACE1 complex was determined and then used to computationally generate a working model of 2a bound in the BACE2 active site. Based upon our SAR studies and structural requirements for BACE2 selectivity, we have designed selective inhibitors $\mathbf{2} \mathbf{d}$ and $\mathbf{3}$ by removing the $\mathrm{P} 2$-sulfonamide, while incorporating an $\mathrm{N}$-methyl amide on the non-prime side. For the most selective inhibitor 2d, we incorporated a propyl chain on the prime side in inhibitor 2a. On the other hand, for inhibitor 31, we incorporated a highly lipophilic 3-trifluoromethylphenyl ring. Inhibitor 31 has shown excellent BACE2 potency and high selectivity over BACE1. Further studies including the design of more selective BACE2 inhibitors are in progress. 


\section{Experimental Section}

\section{General}

Reactions were carried out under an argon atmosphere in either flame- or oven-dried $\left(120^{\circ} \mathrm{C}\right)$ glassware. All reagents and chemicals were purchased from commercial suppliers and used without further purification unless otherwise noted. Anhydrous solvents were obtained as follows: dichloromethane from calcium hydride, diethyl ether and tetrahydrofuran from sodium benzophenone, methanol and ethanol from activated magnesium under argon. All purification procedures were carried out with reagent-grade solvents (purchased form VWR) in air. TLC analysis was conducted using glass-backed thin-layer silica gel chromatography plates (60 a, $250 \mathrm{~mm}$ thickness, F254 indicator). Column chromatography was performed using $230-400$ mesh, 60 a pore diameter silica gel. ${ }^{1} \mathrm{H}$ and ${ }^{13} \mathrm{C}$ NMR spectra were recorded at room temperature on a Bruker AV800, DRX-500 and ARX-400 or a Varian INOVA300. Chemical shifts ( $\delta$ values) are reported in parts per million and are referenced to the deuterated residual solvent peak. NMR data are reported as: $\delta$ value (chemical shift, $J$-value $(\mathrm{Hz})$, integration, where $\mathrm{s}=$ singlet, $\mathrm{d}=$ doublet, $\mathrm{t}=$ triplet, $\mathrm{q}=$ quartet, brs = broad singlet). Low resolution mass analyses were performed on an Agilent 1290 Infinity II spectrometer. High Resolution mass analyses were performed at the Purdue University Campus-wide Mass Spectrometry Center. HPLC analysis was performed on an Agilent 1260 Infinity instrument. All test inhibitors showed purity $>95 \%$ by HPLC analysis.

\section{$N-((2 S, 3 R)-3-H y d r o x y-4-(((2 S, 3 S)-3-h y d r o x y-1-(i s o b u t y l a m i n o)-1-o x o b u t a n-2-y l) a m i n o)-1-$ phenylbutan-2-yl)-3-((R)-2-(methoxymethyl)pyrrolidine-1-carbonyl)benzamide (2f)}

Carboxylic acid $5 \mathbf{a}(16.5 \mathrm{mg}, 0.063 \mathrm{mmol})$ was dissolved in dry $\mathrm{CH}_{2} \mathrm{Cl}_{2}(3.0 \mathrm{~mL})$, then EDCI (22 mg, $0.114 \mathrm{mmol}), \mathrm{HOBt}(15.4 \mathrm{mg}, 0.114 \mathrm{mmol})$ and $N, N$-DIPEA $(20 \mu \mathrm{L}, 0.114$ mmol) were sequentially added. Isosteric amine $\mathbf{1 0 a}(0.057 \mathrm{mmol})$ dissolved in dry $\mathrm{CH}_{2} \mathrm{Cl}_{2}$ $(2 \mathrm{~mL})$ was then added and the reaction mixture was stirred at $25^{\circ} \mathrm{C}$ for $14 \mathrm{~h}$. Saturated aqueous sodium bicarbonate was added and the reaction mixture was extracted three times with $\mathrm{CH}_{2} \mathrm{Cl}_{2}$. The organic layers were dried over anhydrous sodium sulfate, filtered and concentrated under reduced pressure. The residue was purified by silica gel flash chromatography ( $8 \% \mathrm{MeOH}$ in $\mathrm{CH}_{2} \mathrm{Cl}_{2}$ ) affording the title compound as a white amorphous solid (45\% yield). $\delta{ }^{1} \mathrm{H}$ NMR (400 MHz, $\left.\mathrm{CDCl}_{3}\right) \delta 8.08-7.04(\mathrm{~m}, 11 \mathrm{H}), 4.41(\mathrm{br}, 1 \mathrm{H})$, $4.15(\mathrm{br}, 1 \mathrm{H}), 3.83-3.50(\mathrm{~m}, 2 \mathrm{H}), 3.56-3.21(\mathrm{~m}, 4 \mathrm{H}), 3.21-2.63(\mathrm{~m}, 6 \mathrm{H}), 2.26-1.63(\mathrm{~m}$, $J=79.7 \mathrm{~Hz}, 6 \mathrm{H}), 1.65-1.02(\mathrm{~m}, 10 \mathrm{H}), 0.86(\mathrm{~s}, 6 \mathrm{H})$; LRMS-ESI $(\mathrm{m} / \mathrm{z}): 583.3[\mathrm{M}+\mathrm{H}]^{+}$; HRMS-APCI $(\mathrm{m} / \mathrm{z})$ : $[\mathrm{M}+\mathrm{H}]^{+}$calcd for $\mathrm{C}_{32} \mathrm{H}_{47} \mathrm{~N}_{4} \mathrm{O}_{6}, 583.3490$; found 583.3496.

\section{$N-((2 S, 3 R)-3-H y d r o x y-4-(((2 S, 3 S)-3-h y d r o x y-1-(i s o b u t y l a m i n o)-1-o x o h e x a n-2-y l) a m i n o)-1-$ phenylbutan-2-yl)-3-((R)-2-(methoxymethyl)pyrrolidine-1-carbonyl)-5-methylbenzamide (2g)}

Title compound was obtained from acid $\mathbf{5 b}$ and isosteric amine $\mathbf{1 0 b}$ following the procedure described for compound $2 \mathrm{f} .{ }^{1} \mathrm{H}$ NMR $\left(400 \mathrm{MHz}, \mathrm{CDCl}_{3}\right) \delta 7.84(\mathrm{~s}, 1 \mathrm{H}), 7.49(\mathrm{~s}, 1 \mathrm{H}), 7.40$ (s, 2H), $7.37-7.10(\mathrm{~m}, 7 \mathrm{H}), 4.48-4.33(\mathrm{~m}, 2 \mathrm{H}), 3.90-3.78(\mathrm{~m}, 1 \mathrm{H}), 3.78-3.70(\mathrm{~m}, 1 \mathrm{H})$, $3.69-3.53(\mathrm{~m}, 3 \mathrm{H}), 3.36(\mathrm{~s}, 3 \mathrm{H}), 3.31-3.21(\mathrm{~m}, 1 \mathrm{H}), 3.17(\mathrm{~s}, 1 \mathrm{H}), 3.13-2.91(\mathrm{~m}, 6 \mathrm{H})$, $2.89-2.73(\mathrm{~m}, 2 \mathrm{H}), 2.30(\mathrm{~s}, 2 \mathrm{H}), 2.12-1.84(\mathrm{~m}, 4 \mathrm{H}), 1.82-1.64(\mathrm{~m}, 2 \mathrm{H}), 1.57-1.28(\mathrm{~m}$, 4H), $0.98-0.74(\mathrm{~m}, 9 \mathrm{H}) ;{ }^{13} \mathrm{C}$ NMR (200 MHz, $\left.\left.\mathrm{CDCl}_{3}\right) \delta 172.8\right), 169.5,168.0,138.3$, 
$138.0,136.9,134.9,130.3,129.7,129.3,128.5,126.5,123.1,72.5,72.0,71.3,67.2,59.2$, 57.0, 55.1, 50.7, 50.3, 46.6, 36.5, 35.3, 29.7, 28.5, 27.6, 25.1, 21.2, 20.2, 19.1, 14.0. LRMSESI $(\mathrm{m} / \mathrm{z}): 625.3[\mathrm{M}+\mathrm{H}]^{+} ;$HRMS-APCI $(\mathrm{m} / \mathrm{z}):[\mathrm{M}+\mathrm{H}]^{+}$calcd for $\mathrm{C}_{35} \mathrm{H}_{53} \mathrm{~N}_{4} \mathrm{O}_{6}, 625.3960$; found 625.3972 .

\section{$N^{1}$-((2S,3R)-3-Hydroxy-4-(((2S,3S)-3-hydroxy-1-(isobutylamino)-1-oxobutan-2-yl)amino)-1- phenylbutan-2-yl)- $N^{\beta}, 5$-dimethyl- $N^{\beta}-((4-m e t h y l t h i a z o l-2-y l) m e t h y l) i s o p h t h a l a m i d e ~(2 h)$}

Title compound was obtained from acid $\mathbf{6 b}$ and isosteric amine 10a following the procedure described for compound 2 f. ${ }^{1} \mathrm{H}$ NMR $\left(400 \mathrm{MHz}, \mathrm{CDCl}_{3}\right) \delta 7.99-7.69(\mathrm{~m}, 1 \mathrm{H}), 7.69-7.45$ $(\mathrm{m}, 2 \mathrm{H}), 7.46-7.01(\mathrm{~m}, 7 \mathrm{H}), 6.96-6.79(\mathrm{~m}, 1 \mathrm{H}), 5.06-4.70(\mathrm{~m}, 2 \mathrm{H}), 4.50-4.34(\mathrm{~m}, 1 \mathrm{H})$, $4.26-3.96(\mathrm{~m}, 3 \mathrm{H}), 3.97-3.74(\mathrm{~m}, 2 \mathrm{H}), 3.67(\mathrm{~s}, 1 \mathrm{H}), 3.48-3.24(\mathrm{~m}, 1 \mathrm{H}), 3.24-2.98(\mathrm{~m}$, $6 \mathrm{H}), 2.91(\mathrm{~s}, 2 \mathrm{H}), 2.55-2.42(\mathrm{~m}, 3 \mathrm{H}), 2.34(\mathrm{~s}, 3 \mathrm{H}), 1.88-1.73(\mathrm{~m}, 1 \mathrm{H}), 1.24(\mathrm{~d}, J=6.0 \mathrm{~Hz}$, $3 \mathrm{H}), 1.02-0.83(\mathrm{~m}, 6 \mathrm{H}) ;{ }^{13} \mathrm{C} \mathrm{NMR}\left(200 \mathrm{MHz}, \mathrm{CDCl}_{3}\right) \delta 172.6,171.0,167.6,165.0,138.9$, $137.6,134.7,130.4,129.7,129.2,128.7,126.7,122.8,114.8,71.5,68.3,67.7,54.7,50.5$, 48.8, 46.6, 37.7, 36.5, 29.7, 28.5, 21.2, 20.2, 19.1, 17.0. LRMS-ESI $(\mathrm{m} / \mathrm{z}): 624.3[\mathrm{M}+\mathrm{H}]^{+}$; HRMS-APCI $(\mathrm{m} / \mathrm{z})$ : $[\mathrm{M}+\mathrm{H}]^{+}$calcd for $\mathrm{C}_{33} \mathrm{H}_{46} \mathrm{~N}_{5} \mathrm{O}_{5} \mathrm{~S}, 624.3214$; found 624.3220 .

\section{$N^{1}$-((2S,3R)-3-Hydroxy-4-((2S,3S)-3-hydroxy-1-(isobutylamino)-1-oxohexan-2-yl)amino)-1- phenylbutan-2-yl)- $N^{3}$-methyl- $N^{3}$-((4-methylthiazol-2-yl)methyl)isophthalamide (2i)}

Title compound was obtained from acid $\mathbf{6 a}$ and isosteric amine $\mathbf{1 0 b}$ following the procedure described for compound 2 f. ${ }^{1} \mathrm{H}$ NMR $\left(400 \mathrm{MHz}, \mathrm{CDCl}_{3}\right) \delta 7.80-7.68(\mathrm{~m}, 2 \mathrm{H}), 7.56(\mathrm{~d}, \boldsymbol{J}=$ $6.8 \mathrm{~Hz}, 1 \mathrm{H}), 7.41(\mathrm{t}, \boldsymbol{J}=7.7 \mathrm{~Hz}, 1 \mathrm{H}), 7.32-7.01(\mathrm{~m}, 7 \mathrm{H}), 6.89(\mathrm{~s}, 1 \mathrm{H}), 4.89(\mathrm{br}, 2 \mathrm{H}), 4.54-$ $4.36(\mathrm{~m}, 1 \mathrm{H}), 3.86(\mathrm{dd}, \boldsymbol{J}=11.4,5.1 \mathrm{~Hz}, 1 \mathrm{H}), 3.76(\mathrm{~d}, \boldsymbol{J}=4.1 \mathrm{~Hz}, 1 \mathrm{H}), 3.18-2.93(\mathrm{~m}, 8 \mathrm{H})$, $2.91-2.73(\mathrm{~m}, 2 \mathrm{H}), 2.46(\mathrm{~s}, 3 \mathrm{H}), 1.77(\mathrm{dt}, \boldsymbol{J}=13.4,6.7 \mathrm{~Hz}, 1 \mathrm{H}), 1.60-1.19(\mathrm{~m}, 6 \mathrm{H}), 1.01$ $-0.83(\mathrm{~m}, 9 \mathrm{H}) ;{ }^{13} \mathrm{C} \mathrm{NMR}\left(200 \mathrm{MHz}, \mathrm{CDCl}_{3}\right) \delta 172.6,170.8,167.2,164.9,152.5,137.7$, $135.4,134.9,129.9,129.6,129.5,129.2,128.6,127.8,126.7,125.9,114.8,113.9,109.8$, 72.1, 71.1, 67.0, 54.8, 50.3, 48.9, 46.6, 37.8, 36.6, 35.5, 29.7, 28.4, 20.2, 19.1, 17.0, 14.0. LRMS-ESI $(\boldsymbol{m} / z): 638.3[\mathrm{M}+\mathrm{H}]^{+} ;$HRMS-APCI $(\boldsymbol{m} / z):[\mathrm{M}+\mathrm{H}]^{+}$calcd for $\mathrm{C}_{34} \mathrm{H}_{48} \mathrm{~N}_{5} \mathrm{O}_{5} \mathrm{~S}$, 638.3371; found 638.3380 .

\section{$N^{1}$-((2S,3R)-3-Hydroxy-4-((2S,3S)-3-hydroxy-1-(isobutylamino)-1-oxohexan-2-yl)amino)-1- phenylbutan-2-yl)- $N^{3}, 5$-dimethyl- $N^{3}$-((4-methylthiazol-2-yl)methyl)isophthalamide (2j)}

Title compound was obtained from acid $6 \mathrm{~b}$ and isosteric amine $10 \mathrm{~b}$ following the procedure described for compound 2 f. ${ }^{1} \mathrm{H}$ NMR $\left(400 \mathrm{MHz}, \mathrm{CDCl}_{3}\right) \delta \mathbf{7 . 6 4}-7.46(\mathrm{~m}, 2 \mathrm{H}), 7.44-7.17$ (m, 6H), $7.10(\mathrm{~s}, 2 \mathrm{H}), 6.89(\mathrm{~s}, 1 \mathrm{H}), 4.91(\mathrm{~s}, 2 \mathrm{H}), 4.43(\mathrm{~s}, 1 \mathrm{H}), 3.87(\mathrm{~s}, 1 \mathrm{H}), 3.74(\mathrm{~s}, 1 \mathrm{H}), 3.33$ - $2.94(\mathrm{~m}, 9 \mathrm{H}), 2.84(\mathrm{~s}, 2 \mathrm{H}), 2.46(\mathrm{~s}, 3 \mathrm{H}), 2.37(\mathrm{~s}, 3 \mathrm{H}), 1.86-1.70(\mathrm{~m}, 1 \mathrm{H}), 1.55-1.18(\mathrm{~m}$, $6 \mathrm{H}), 1.03-0.81(\mathrm{~m}, \boldsymbol{J}=6.5 \mathrm{~Hz}, 9 \mathrm{H}) ;{ }^{13} \mathrm{C} \mathrm{NMR}\left(200 \mathrm{MHz}, \mathrm{CDCl}_{3}\right) \delta 172.7,171.0,167.6$, 165.0, 152.5, 138.9, 137.7, 135.4, 134.8, 130.1, 129.6, 129.5, 129.3, 128.6, 126.7, 122.8, $114.8,113.9,72.1,71.2,67.0,54.7,48.9,46.6,37.8,36.6,35.5,29.7,28.5,21.2,20.2,19.1$, 17.0, 14.1, 13.9. LRMS-ESI $(\boldsymbol{m} / \mathbf{z}): 652.3[\mathrm{M}+\mathrm{H}]^{+}$; HRMS-APCI $(\boldsymbol{m} / z):[\mathrm{M}+\mathrm{H}]^{+}$calcd for $\mathrm{C}_{35} \mathrm{H}_{50} \mathrm{~N}_{5} \mathrm{O}_{5} \mathrm{~S}, 652.3527$; found 652.3531 . 
$N^{1}$-((2S,3R)-3-Hydroxy-4-(((1R,2S)-2-hydroxy-1-(3-methoxyphenyl)propyl)ammo)-1phenylbutan-2-yl)-5-( $N$-methylmethylsulfonamido)- $N^{3}-((R)-1-$ phenylethyl)isophthalamide

(3a)

Title compound was obtained from acid $\mathbf{4 d}$ and the free amine of Boc compound $\mathbf{1 7 a}$ following the procedure described for compound $2 \mathrm{f} .{ }^{1} \mathrm{H} \mathrm{NMR}\left(300 \mathrm{MHz}, \mathrm{CDCl}_{3}\right) \delta 8.62(\mathrm{~d}$, $\boldsymbol{J}=8.0 \mathrm{~Hz}, 1 \mathrm{H}), 8.15(\mathrm{~s}, 1 \mathrm{H}), 7.94-7.83(\mathrm{~m}, 2 \mathrm{H}), 7.42-7.12(\mathrm{~m}, 13 \mathrm{H}), 7.04(\mathrm{br}, 1 \mathrm{H}), 6.87$ $-6.79(\mathrm{~m}, 3 \mathrm{H}), 5.37-5.23(\mathrm{~m}, 1 \mathrm{H}), 4.56-4.40(\mathrm{~m}, 1 \mathrm{H}), 4.15(\mathrm{dd}, \boldsymbol{J}=6.4,3.7 \mathrm{~Hz}, 1 \mathrm{H})$, $3.84-3.77(\mathrm{~m}, 3 \mathrm{H}), 3.75-3.65(\mathrm{~m}, 1 \mathrm{H}), 3.51(\mathrm{~d}, \boldsymbol{J}=3.5 \mathrm{~Hz}, 1 \mathrm{H}), 3.33-3.27(\mathrm{~m}, 3 \mathrm{H}), 3.05$ $(\mathrm{dd}, \boldsymbol{J}=13.9,7.5 \mathrm{~Hz}, 1 \mathrm{H}), 2.88-2.75(\mathrm{~m}, 5 \mathrm{H}), 2.75-2.64(\mathrm{~m}, 1 \mathrm{H}), 1.58(\mathrm{~d}, \boldsymbol{J}=6.9 \mathrm{~Hz}$, $3 \mathrm{H}), 0.95(\mathrm{~d}, \boldsymbol{J}=6.4 \mathrm{~Hz}, 5 \mathrm{H})$.

\section{$N^{1}-((2 S, 3 R)-3-H y d r o x y-4-(((1 R, 2 S)-2-h y d r o x y-1-(3-m e t h o x y p h e n y l) p r o p y l) a m m o)-1-$ phenylbutan-2-yl)- $N^{\beta}$-methyl-5-( $N$-methylmethylsulfonamido)- $N^{\beta}-((R)-1-$ phenylethyl)isophthalamide (3b)}

Title compound was obtained from acid $\mathbf{4 c}$ and the free amine of Boc compound 17a following the procedure described for compound 2 f. ${ }^{1} \mathrm{H} \mathrm{NMR}\left(300 \mathrm{MHz}, \mathrm{CDCl}_{3}\right) \delta 7.93-$ $7.72(\mathrm{~m}, 2 \mathrm{H}), 7.59(\mathrm{~s}, 1 \mathrm{H}), 7.48-7.03(\mathrm{~m}, 12 \mathrm{H}), 6.99-6.72(\mathrm{~m}, 3 \mathrm{H}), 6.11(\mathrm{~s}, 0.5 \mathrm{H}), 5.01$ (s, 0.5H), $4.49(\mathrm{~s}, 1 \mathrm{H}), 4.20(\mathrm{~s}, 1 \mathrm{H}), 3.79(\mathrm{~s}, 3 \mathrm{H}), 3.77-3.63(\mathrm{~m}, 2 \mathrm{H}), 3.59(\mathrm{~s}, 1 \mathrm{H}), 3.40-$ $3.20(\mathrm{~m}, 3 \mathrm{H}), 3.17-2.97(\mathrm{~m}, 2 \mathrm{H}), 2.97-2.69(\mathrm{~m}, 7 \mathrm{H}), 2.70-2.53(\mathrm{~m}, 2 \mathrm{H}), 1.61(\mathrm{~d}, J=6.8$ $\mathrm{Hz}, 3 \mathrm{H}), 1.02(\mathrm{~d}, J=5.9 \mathrm{~Hz}, 3 \mathrm{H})$. LRMS-ESI $(\mathrm{m} / \mathrm{z}): 717.8[\mathrm{M}+\mathrm{H}]^{+}$; HRMS-ESI $(\mathrm{m} / \mathrm{z}):[\mathrm{M}$ $+\mathrm{H}]^{+}$calcd for $\mathrm{C}_{39} \mathrm{H}_{49} \mathrm{~N}_{4} \mathrm{O}_{7} \mathrm{~S}, 717.3317$; found 717.3310 .

\section{$N^{1}$ - ((2S,3R)-3-Hydroxy-4-(((1R,2S)-2-hydroxy-1-(3-methoxyphenyl)propyl)ammo)-1- phenylbutan-2-yl)- $N^{\beta}$-methyl- $N^{\beta}-((R)-1-$ phenylethyl)isophthalamide (3c)}

Title compound was obtained from acid $\mathbf{4 a}$ and the free amine of Boc compound 17a following the procedure described for compound $2 \mathrm{f} .{ }^{1} \mathrm{H} \mathrm{NMR}\left(500 \mathrm{MHz}, \mathrm{CDCl}_{3}\right) \delta 7.84(\mathrm{~d}$, $\boldsymbol{J}=7.5 \mathrm{~Hz}, 2 \mathrm{H}), 7.54(\mathrm{br}, 1 \mathrm{H}), 7.51-7.15(\mathrm{~m}, 13 \mathrm{H}), 6.95(\mathrm{~d}, \boldsymbol{J}=8.5 \mathrm{~Hz}, 2 \mathrm{H}), 6.92-6.83$ $(\mathrm{m}, 1 \mathrm{H}), 6.21(\mathrm{~s}, 0.5 \mathrm{H}), 5.03(\mathrm{~s}, 0.5 \mathrm{H}), 4.52(\mathrm{~s}, 1 \mathrm{H}), 4.19(\mathrm{~s}, 1 \mathrm{H}), 3.94-3.81(\mathrm{~m}, 3 \mathrm{H}), 3.81-$ $3.68(\mathrm{~m}, 1 \mathrm{H}), 3.67-3.57(\mathrm{~m}, 1 \mathrm{H}), 3.11(\mathrm{~s}, 2 \mathrm{H}), 2.99(\mathrm{dd}, \boldsymbol{J}=14.1,6.3 \mathrm{~Hz}, 2 \mathrm{H}), 2.95-2.70$ $(\mathrm{m}, 4 \mathrm{H}), 2.63(\mathrm{~s}, 2 \mathrm{H}), 1.77-1.52(\mathrm{~m}, 3 \mathrm{H}), 1.14-1.05(\mathrm{~m}, 3 \mathrm{H}) ;{ }^{13} \mathrm{C} \mathrm{NMR}(125 \mathrm{MHz}$, $\left.\mathrm{CDCl}_{3}\right) \delta 171.3,167.7,160.1,140.9,138.2,137.1,129.8,130.0,128.8,128.1,127.8,127.0$, 125.9, 121.1, 114.6, 113.2, 71.0, 70.4, 68.9, 55.6, 55.4, 49.6, 37.4, 20.1, 15.8. LRMS-ESI $(\boldsymbol{m} / \mathbf{z}): 610.0[\mathrm{M}+\mathrm{H}]^{+}, 632.2[\mathrm{M}+\mathrm{H}]^{+}$; HRMS-ESI $(\boldsymbol{m} / z):[\mathrm{M}+\mathrm{H}]^{+}$calcd for $\mathrm{C}_{37} \mathrm{H}_{44} \mathrm{~N}_{3} \mathrm{O}_{5}$, 610.3276; found 610.3270 .

\section{$N^{1}$-((2S,3R)-3-Hydroxy-4-(((1R,2S)-2-hydroxy-1-(3-methoxyphenyl)propyl)amino)-1- phenylbutan-2-yl)- $N^{\beta}, 5$-dimethyl- $N^{\beta}-((R)-1$-phenylethyl)isophthalamide (3d)}

Title compound was obtained from acid $\mathbf{4 b}$ and the free amine of Boc compound 17a following the procedure described for compound $2 \mathbf{2 f} .{ }^{1} \mathrm{H} \mathrm{NMR}\left(500 \mathrm{MHz}, \mathrm{CDCl}_{3}\right) \delta 7.70-$ $7.57(\mathrm{~m}, 2 \mathrm{H}), 7.54-7.17(\mathrm{~m}, 13 \mathrm{H}), 7.08-6.84(\mathrm{~m}, 3 \mathrm{H}), 6.21(\mathrm{~s}, 0.5 \mathrm{H}), 5.03(\mathrm{~s}, 0.5 \mathrm{H}), 4.51$ (s, 1H), $4.19(\mathrm{~s}, 1 \mathrm{H}), 3.85(\mathrm{~s}, 3 \mathrm{H}), 3.80-3.68(\mathrm{~m}, 1 \mathrm{H}), 3.62(\mathrm{~s}, 1 \mathrm{H}), 3.10(\mathrm{~s}, 1 \mathrm{H}), 3.07-$ $2.86(\mathrm{~m}, 3 \mathrm{H}), 2.86-2.70(\mathrm{~m}, 3 \mathrm{H}), 2.62(\mathrm{~s}, 2 \mathrm{H}), 2.44(\mathrm{~s}, 3 \mathrm{H}), 1.75-1.58(\mathrm{~m}, 3 \mathrm{H}), 1.11(\mathrm{~d}, J$ $=6.3 \mathrm{~Hz}, 3 \mathrm{H}) ;{ }^{13} \mathrm{C} \mathrm{NMR}\left(125 \mathrm{MHz}, \mathrm{CDCl}_{3}\right) \delta 168.0,160.1,140.7,138.1,137.2,135.4$, 130.2, 129.6, 129.4, 129.0, 128.1, 127.8, 127.1, 122.9, 121.2, 114.6, 113.3, 71.1,70.4, 68.9, 
55.6, 55.3, 49.5, 37.3, 30.2, 21.8, 20.2. LRMS-ESI $(\mathrm{m} / \mathrm{z}): 624.3[\mathrm{M}+\mathrm{H}]^{+}$; HRMS-APCI $(\mathrm{m} / \mathrm{z}):[\mathrm{M}+\mathrm{H}]^{+}$calcd for $\mathrm{C}_{38} \mathrm{H}_{46} \mathrm{~N} 3 \mathrm{O} 5,624.3432$; found 624.3437 .

$N^{1}$-((2S,3R)-3-Hydroxy-4-(((1R,2S)-2-hydroxy-1-(3-methoxyphenyl)pentyl)amino)-1phenylbutan-2-yl)- $N^{\beta}$-methyl- $N^{\beta}-((R)-1$-phenylethyl)isophthalamide (3e)

Title compound was obtained from acid $\mathbf{4 a}$ and the free amine of Boc compound $\mathbf{1 7} \mathbf{b}$ following the procedure described for compound $2 \mathbf{2 f}{ }^{1} \mathrm{H} \mathrm{NMR}\left(800 \mathrm{MHz}, \mathrm{CDCl}_{3}\right) \delta 7.96-$ $7.73(\mathrm{~m}, 2 \mathrm{H}), 7.51(\mathrm{~d}, \boldsymbol{J}=7.5 \mathrm{~Hz}, 1 \mathrm{H}), 7.46-7.37(\mathrm{~m}, 4 \mathrm{H}), 7.34(\mathrm{dd}, \boldsymbol{J}=15.2,7.5 \mathrm{~Hz}, 1 \mathrm{H})$, $7.28-7.22(\mathrm{~m}, 5 \mathrm{H}), 7.22-7.14(\mathrm{~m}, 2 \mathrm{H}), 6.92(\mathrm{~d}, \boldsymbol{J}=7.9 \mathrm{~Hz}, 2 \mathrm{H}), 6.85-6.82(\mathrm{~m}, 1 \mathrm{H}), 6.16$ (s, 0.5H), $5.01(\mathrm{~s}, 0.5 \mathrm{H}), 4.48(\mathrm{~s}, 1 \mathrm{H}), 3.97(\mathrm{~s}, 1 \mathrm{H}), 3.82(\mathrm{~s}, 3 \mathrm{H}), 3.73(\mathrm{dd}, \boldsymbol{J}=12.6,3.2 \mathrm{~Hz}$, 1H), $3.61(\mathrm{~d}, \boldsymbol{J}=1.9 \mathrm{~Hz}, 1 \mathrm{H}), 3.09(\mathrm{~s}, 1 \mathrm{H}), 2.97(\mathrm{dd}, \boldsymbol{J}=14.1,6.3 \mathrm{~Hz}, 1 \mathrm{H}), 2.92-2.81(\mathrm{~m}$, 1H), $2.84-2.69$ (m, 2H), 2.59 (s, 1H), $1.70-1.56$ (m, 3H), $1.40-1.25$ (m, 4H), 1.19 (td, $\boldsymbol{J}$ $=9.1,4.7 \mathrm{~Hz}, 1 \mathrm{H}), 0.89-0.80(\mathrm{~m}, 3 \mathrm{H}) ;{ }^{13} \mathrm{C} \mathrm{NMR}\left(125 \mathrm{MHz}, \mathrm{CDCl}_{3}\right) \delta$ 167.5, 159.9, $140.8,138.0,136.9,129.8,129.6,129.8,128.7,127.9,127.7,126.9,125.8,121.0,114.5$, $113.0,70.9,70.3,68.8,55.5,55.30,53.8,49.5,37.2,32.2,20.0,15.7$. LRMS-ESI $(\boldsymbol{m} / \mathbf{z})$ : $638.3[\mathrm{M}+\mathrm{H}]^{+}$; HRMS-APCI $(\boldsymbol{m} / z)$ : $[\mathrm{M}+\mathrm{H}]^{+}$calcd for $\mathrm{C}_{39} \mathrm{H}_{48} \mathrm{~N}_{3} \mathrm{O}_{5}, 638.3589$; found 638.3596.

$N^{1}$-((2S,3R)-3-Hydroxy-4-(((1R,2S)-2-hydroxy-1-(3-methoxyphenyl)pentyl)ammo)-1phenylbutan-2-yl)- $N^{\beta}, 5$-dimethyl- $N^{\beta}-((R)$-1-phenylethyl)isophthalamide (3f)

Title compound was obtained from acid $\mathbf{4 b}$ and the free amine of Boc compound $\mathbf{1 7 b}$ following the procedure described for compound $2 \mathrm{f}$. ${ }^{1} \mathrm{H}$ NMR $\left(300 \mathrm{MHz}, \mathrm{CDCl}_{3}\right) \delta 7.82(\mathrm{~s}$, 1H), $7.56(\mathrm{~d}, \boldsymbol{J}=8.8 \mathrm{~Hz}, 2 \mathrm{H}), 7.50-7.07(\mathrm{~m}, 12 \mathrm{H}), 6.90(\mathrm{~d}, \boldsymbol{J}=6.6 \mathrm{~Hz}, 2 \mathrm{H}), 6.81(\mathrm{~d}, \boldsymbol{J}=$ $8.1 \mathrm{~Hz}, 1 \mathrm{H}), 6.13(\mathrm{~s}, 0.5 \mathrm{H}), 4.98(\mathrm{~s}, 0.5 \mathrm{H}), 4.44(\mathrm{~s}, 1 \mathrm{H}), 3.95(\mathrm{~s}, 1 \mathrm{H}), 3.77(\mathrm{~s}, 3 \mathrm{H}), 3.75-$ $3.62(\mathrm{~m}, 1 \mathrm{H}), 3.58(\mathrm{~s}, 1 \mathrm{H}), 3.17-2.90(\mathrm{~m}, 3 \mathrm{H}), 2.92-2.48(\mathrm{~m}, 6 \mathrm{H}), 2.36(\mathrm{~s}, 3 \mathrm{H}), 1.70-$ $1.42(\mathrm{~m}, 4 \mathrm{H}), 1.44-1.09(\mathrm{~m}, 4 \mathrm{H}), 0.83(\mathrm{t}, \boldsymbol{J}=6.9 \mathrm{~Hz}, 3 \mathrm{H}) ;{ }^{13} \mathrm{C} \mathrm{NMR}\left(125 \mathrm{MHz}, \mathrm{CDCl}_{3}\right) \delta$ $168.1,160.2,140.8,138.5,137.9,137.3,135.5,130.7,130.0,129.1,129.3,128.7,128.4$, $128.1,127.98,127.6,127.4,126.8,123.0,121.7,121.0,115.1,114.3,113.7,113.0,71.2$, 70.4, 69.0, 55.7, 55.4, 49.6, 37.4, 32.4, 30.2, 21.8, 20.2, 18.1, 15.9. LRMS-ESI $(\mathbf{m} / \mathbf{z}): 652.4$ $[\mathrm{M}+\mathrm{H}]^{+}$; HRMS-APCI $(\boldsymbol{m} / z)$ : $[\mathrm{M}+\mathrm{H}]^{+}$calcd for $\mathrm{C}_{40} \mathrm{H}_{50} \mathrm{~N}_{3} \mathrm{O}_{5}, 652.3745$; found 652.3749 .

\section{$N^{1}-((2 S, 3 R)-3-H y d r o x y-4-(((1 R, 2 S)-2-h y d r o x y-1-p h e n y l p e n t y l) a m m o)-1-p h e n y l b u t a n-2-y l)-N^{3}-$ methyl- $N^{\beta}-((R)-1-$ phenylethyl)isophthalamide (3g)}

Title compound was obtained from acid $\mathbf{4 a}$ and the free amine of Boc compound 17c following the procedure described for compound $2 \mathrm{f}$. ${ }^{1} \mathrm{H}$ NMR $\left(300 \mathrm{MHz}, \mathrm{CDCI}_{3}\right) \delta 8.03$ (s, 1H), $7.80(\mathrm{~s}, 2 \mathrm{H}), 7.62-7.10(\mathrm{~m}, 17 \mathrm{H}), 6.13(\mathrm{~s}, 1 \mathrm{H}), 4.98(\mathrm{~s}, 1 \mathrm{H}), 4.56-4.39(\mathrm{~m}, 1 \mathrm{H}), 3.95$ $(\mathrm{s}, 1 \mathrm{H}), 3.68(\mathrm{~s}, 1 \mathrm{H}), 3.60(\mathrm{~d}, J=3.3 \mathrm{~Hz}, 1 \mathrm{H}), 3.08(\mathrm{dd}, J=13.8,7.6 \mathrm{~Hz}, 2 \mathrm{H}), 2.92(\mathrm{dd}, J=$ 14.0, $6.4 \mathrm{~Hz}, 2 \mathrm{H}), 2.88-2.65(\mathrm{~m}, 4 \mathrm{H}), 2.57(\mathrm{~s}, 2 \mathrm{H}), 1.68-1.42(\mathrm{~m}, 3 \mathrm{H}), 1.37-1.02(\mathrm{~m}$, $4 \mathrm{H}), 0.83(\mathrm{t}, J=7.1 \mathrm{~Hz}, 3 \mathrm{H}) ;{ }^{13} \mathrm{C} \mathrm{NMR}\left(200 \mathrm{MHz}, \mathrm{CDCI}_{3}\right) \delta 167.4,137.7,136.7,129.3$, $128.8,128.4,127.5,126.6,126.5,73.5,70.5,67.5,55.1,49.0,36.9,36.3,29.7,19.2$. LRMSESI $(\mathrm{m} / \mathrm{z}): 608.3[\mathrm{M}+\mathrm{H}]^{+}$; HRMS-ESI $(\mathrm{m} / \mathrm{z}):[\mathrm{M}+\mathrm{H}]^{+}$calcd for $\mathrm{C}_{38} \mathrm{H}_{46} \mathrm{~N}_{3} \mathrm{O}_{4}, 608.3483$; found 608.3493 . 
$N^{1}$-((2S,3R)-3-Hydroxy-4-(((1R,2S)-2-hydroxy-1-phenylpentyl)amino)-1-phenylbutan-2-yl)$N 3,5$-dimethyl- $N^{\beta}-((R)-1-$ phenylethyl)isophthalamide (3h)

Title compound was obtained from acid $\mathbf{4 b}$ and the free amine of Boc compound $\mathbf{1 7 c}$ following the procedure described for compound $2 \mathbf{2 f}^{1} \mathrm{H} \mathrm{NMR}\left(500 \mathrm{MHz}, \mathrm{CDCl}_{3}\right) \delta 8.49-$ $8.26(\mathrm{~m}, J=24.0 \mathrm{~Hz}, 2 \mathrm{H}), 8.15(\mathrm{~d}, J=19.2 \mathrm{~Hz}, 2 \mathrm{H}), 8.01-7.61(\mathrm{~m}, 15 \mathrm{H}), 6.67(\mathrm{~s}, 1 \mathrm{H})$, $5.02(\mathrm{~s}, 1 \mathrm{H}), 4.64(\mathrm{~s}, 2 \mathrm{H}), 4.24(\mathrm{~s}, 2 \mathrm{H}), 3.80-3.60(\mathrm{~m}, 2 \mathrm{H}), 3.58-3.17(\mathrm{~m}, 2 \mathrm{H}), 3.12(\mathrm{~s}$, $2 \mathrm{H}), 2.91(\mathrm{~s}, 2 \mathrm{H}), 2.14(\mathrm{~s}, 3 \mathrm{H}), 2.01(\mathrm{~s}, 2 \mathrm{H}), 1.88-1.57(\mathrm{~m}, 5 \mathrm{H}), 1.42-1.28(\mathrm{~m}, 3 \mathrm{H}) ;{ }^{13} \mathrm{C}$ NMR $\left(200 \mathrm{MHz}, \mathrm{CDCl}_{3}\right) \delta 167.4,137.6,136.8,130.8,129.6,129.4,128.5,127.8,127.5$, 126.6, 70.6, 67.4, 54.9, 48.8, 36.7, 36.3, 29.7, 22.7, 21.3, 19.1, 14.0. LRMS-ESI $(\mathrm{m} / \mathrm{z})$ : $622.3[\mathrm{M}+\mathrm{H}]^{+}$; HRMS-ESI $(\mathrm{m} / \mathrm{z}):[\mathrm{M}+\mathrm{H}]^{+}$calcd for $\mathrm{C}_{39} \mathrm{H}_{47} \mathrm{~N}_{3} \mathrm{O}_{4}, 622.3640$; found 622.3635 .

\section{$N^{1}$-((2S,3R)-3-Hydroxy-4-((3-methoxybenzyl)ammo)-1-phenylbutan-2-yl)- $N^{3}$-methyl- $N^{\beta}$ - $((R)$-1-phenylethyl)isophthalamide (3i)}

Title compound was obtained from acid $4 \mathbf{a}$ and isosteric amine $\mathbf{1 8 b}$ following the procedure described for compound 2f. ${ }^{1} \mathrm{H}$ NMR $\left(400 \mathrm{MHz}, \mathrm{CDCl}_{3}\right) \delta 7.75(\mathrm{~s}, 1 \mathrm{H}), 7.67(\mathrm{~d}, J=7.5 \mathrm{~Hz}$, $1 \mathrm{H}), 7.52(\mathrm{~d}, J=7.4 \mathrm{~Hz}, 1 \mathrm{H}), 7.47-7.12(\mathrm{~m}, 12 \mathrm{H}), 7.05(\mathrm{br}, 1 \mathrm{H}), 6.99-6.89(\mathrm{~m}, 2 \mathrm{H}), 6.84$ $(\mathrm{d}, J=7.6 \mathrm{~Hz}, 1 \mathrm{H}), 4.49-4.34(\mathrm{~m}, 1 \mathrm{H}), 3.96-3.74(\mathrm{~m}, 6 \mathrm{H}), 3.72-3.45(\mathrm{~m}, 2 \mathrm{H}), 3.13-$ $2.97(\mathrm{~m}, 2 \mathrm{H}), 2.93-2.77(\mathrm{~m}, 2 \mathrm{H}), 2.78-2.57(\mathrm{~m}, 2 \mathrm{H}), 1.62(\mathrm{~d}, J=6.8 \mathrm{~Hz}, 3 \mathrm{H}) ;{ }^{13} \mathrm{C}$ NMR $\left(200 \mathrm{MHz}, \mathrm{CDCl}_{3}\right) \delta 170.7,167.2,159.9,137.8,129.7,129.3,128.8,128.7,127.7,127.5$, 126.6, 120.9, 114.2, 113.3, 70.4, 55.3, 54.2, 53.4, 50.5, 36.4, 29.7. LRMS-ESI $(\mathrm{m} / \mathrm{z}): 566.3$ $[\mathrm{M}+\mathrm{H}]^{+}$; HRMS-ESI $(\mathrm{m} / \mathrm{z})$ : $[\mathrm{M}+\mathrm{H}]^{+}$calcd for $\mathrm{C}_{35} \mathrm{H}_{40} \mathrm{~N}_{3} \mathrm{O}_{4}, 566.3013$; found 566.3009 .

\section{$N^{1}$-((2S,3R)-3-Hydroxy-4-((3-methoxybenzyl)ammo)-1-phenylbutan-2-yl)-N3,5-dimethyl- $N^{3}$ - ((R)-1-phenylethyl)isophthalamide (3j)}

Compound was synthesized as reported. ${ }^{36}{ }^{1} \mathrm{H},{ }^{13} \mathrm{C}$, LRMS and HRMS are identical to those reported in literature. ${ }^{36}$

\section{$N^{1}-((2 S, 3 R)-3-H y d r o x y-1-p h e n y l-4-((3-(t r i f l u o r o m e t h y l) b e n z y l) a m i n o) b u t a n-2-y l)-N^{3}-$ methyl- $N^{3}$-((R)-1-phenylethyl)isophthalamide (3k)}

Title compound was obtained from acid $4 \mathbf{a}$ and isosteric amine 18a following the procedure described for compound 2 f. ${ }^{1} \mathrm{H}$ NMR $\left(400 \mathrm{MHz}, \mathrm{CDCl}_{3}\right) \delta$ 7.85-- $7.08(\mathrm{~m}, 18 \mathrm{H}), 6.94(\mathrm{br}$, $1 \mathrm{H}), 6.14(\mathrm{br}, 1 \mathrm{H}), 4.92(\mathrm{~s}, 1 \mathrm{H}), 4.50-4.23(\mathrm{~m}, 1 \mathrm{H}), 3.86(\mathrm{q}, J=13.5 \mathrm{~Hz}, 2 \mathrm{H}), 3.75-3.57$ $(\mathrm{m}, 1 \mathrm{H}), 3.17-2.90(\mathrm{~m}, 3 \mathrm{H}), 2.91-2.65(\mathrm{~m}, 4 \mathrm{H}), 2.66-2.43(\mathrm{~m}, 1 \mathrm{H}), 1.72-1.47(\mathrm{~m}$, $3 \mathrm{H}) ;{ }^{13} \mathrm{C}$ NMR $\left(200 \mathrm{MHz}, \mathrm{CDCl}_{3}\right) \delta 170.6,167.2,140.1,137.6,137.2,131.7,131.4,131.3$, 130.9, 129.3, 128.8, 129.0, 127.9, 127.7, 127.4, 126.7, 126.5, 126.3, 126.4, 126.42, 125.44, 124.2, 123.4, 113.9, 70.7, 54.0, 53.3, 50.7, 36.4, 29.7, 22.70. LRMS-ESI ( $\mathrm{m} / \mathrm{z}): 604.3$ [M $+\mathrm{H}]^{+}$; HRMS-APCI $(\mathrm{m} / \mathrm{z}):[\mathrm{M}+\mathrm{H}]^{+}$calcd for $\mathrm{C}_{35} \mathrm{H}_{37} \mathrm{~F}_{3} \mathrm{~N}_{3} \mathrm{O}_{3}, 604.2782$; found 604.2785 .

\section{$N^{1}$-((2S,3R)-3-Hydroxy-1-phenyl-4-((3-(trifluoromethyl)benzyl)ammo)butan-2-yl)- $N^{3}, 5-$ dimethyl- $N^{3}-((R)-1-$ phenylethyl)isophthalamide (3I)}

Title compound was obtained from acid $\mathbf{4 b}$ and isosteric amine 18a following the procedure described for compound $2 \mathbf{f} .{ }^{1} \mathrm{H}$ NMR $\left(300 \mathrm{MHz}, \mathrm{CDCl}_{3}\right){ }^{1} \mathrm{H} \mathrm{NMR}\left(800 \mathrm{MHz}, \mathrm{CDCl}_{3}\right) \delta$ $7.62(\mathrm{~s}, 1 \mathrm{H}), 7.56(\mathrm{dd}, \boldsymbol{J}=21.7,7.5 \mathrm{~Hz}, 2 \mathrm{H}), 7.52-7.38(\mathrm{~m}, 5 \mathrm{H}), 7.39-7.30(\mathrm{~m}, 3 \mathrm{H}), 7.27$ 
- 7.12 (m, 5H), $6.85-6.69$ (m, 1H), 6.16 (br, 1H), 4.94 (br, 1H), $4.43-4.30$ (m, 1H), 3.92 $(\mathrm{dd}, \boldsymbol{J}=37.4,13.4 \mathrm{~Hz}, 2 \mathrm{H}), 3.79-3.64(\mathrm{~m}, 1 \mathrm{H}), 3.10(\mathrm{dd}, \boldsymbol{J}=14.2,5.0 \mathrm{~Hz}, 2 \mathrm{H}), 2.99(\mathrm{~s}$, $1 \mathrm{H}), 2.91-2.69(\mathrm{~m}, 4 \mathrm{H}), 2.56(\mathrm{~s}, 2 \mathrm{H}), 2.36(\mathrm{~s}, 3 \mathrm{H}), 1.68-1.49(\mathrm{~m}, 3 \mathrm{H}) ;{ }^{13} \mathrm{C}$ NMR $(200$ $\left.\mathrm{MHz}, \mathrm{CDCl}_{3}\right) \delta 170.8,167.5,139.9,137.6,131.8,131.2,130.2,130.4,130.2,130.0,130.0$, 129.3. 127.5, 127.2, 126.9, 126.6, 125.2, 124.8, 124.4, 123.4, 70.8, 53.8, 53.2, 50.6, 36.4, 29.7, 21.2. LRMS-ESI $(\boldsymbol{m} / z): 618.3[\mathrm{M}+\mathrm{H}]^{+}$; HRMS-APCI $(\boldsymbol{m} / z):[\mathrm{M}+\mathrm{H}]^{+}$calcd for $\mathrm{C}_{36} \mathrm{H}_{39} \mathrm{~F}_{3} \mathrm{~N}_{3} \mathrm{O}_{3}$, 618.2938; found 618.2945.

\section{$N^{1}$-((2S,3R)-3-Hydroxy-4-((3-methoxybenzyl)amino)-1-phenylbutan-2-yl)- $N^{3}-$ methyl- $N^{3}-((4-$ methyloxazol-2-yl)methyl)isophthalamide (3m)}

Title compound was obtained from acid $\mathbf{7 a}$ and isosteric amine $\mathbf{1 8 b}$ following the procedure described for compound 2f. ${ }^{1} \mathrm{H}$ NMR $\left(800 \mathrm{MHz}, \mathrm{CDCl}_{3}\right) \delta 7.87(\mathrm{~d}, J=47.0 \mathrm{~Hz}, 1 \mathrm{H}), 7.80-$ $7.62(\mathrm{~m}, 2 \mathrm{H}), 7.63-7.46(\mathrm{~m}, 1 \mathrm{H}), 7.36(\mathrm{dd}, J=20.3,12.6 \mathrm{~Hz}, 5 \mathrm{H}), 7.24-7.15(\mathrm{~m}, 1 \mathrm{H})$, $7.16-7.10(\mathrm{~m}, 1 \mathrm{H}), 7.01(\mathrm{~s}, 1 \mathrm{H}), 6.94(\mathrm{~d}, J=7.3 \mathrm{~Hz}, 1 \mathrm{H}), 6.82(\mathrm{dd}, J=8.3,2.2 \mathrm{~Hz}, 1 \mathrm{H})$, $4.85-4.77(\mathrm{~m}, 1 \mathrm{H}), 4.41(\mathrm{~s}, 1 \mathrm{H}), 4.35(\mathrm{~d}, J=5.3 \mathrm{~Hz}, 1 \mathrm{H}), 4.13-4.04(\mathrm{~m}, 2 \mathrm{H}), 4.01-3.94$ $(\mathrm{m}, 1 \mathrm{H}), 3.72(\mathrm{~s}, 3 \mathrm{H}), 3.15-3.03(\mathrm{~m}, 3 \mathrm{H}), 2.98-2.86(\mathrm{~m}, 3 \mathrm{H}), 2.22-2.10(\mathrm{~m}, 3 \mathrm{H}) ;{ }^{13} \mathrm{C}$ NMR (200 MHz, $\left.\mathrm{CDCl}_{3}\right) \delta 167.4,159.9,159.3,137.8,136.9,136.2,135.8,135.5,135.2$, $134.2,130.0,129.4,128.6,128.5,127.8,126.5,126.1,124.5,121.7,114.8,114.7,114.6$, 113.9, 70.0, 55.3, 54.1, 52.3, 50.4, 35.9, 29.7. LRMS-ESI $(\mathrm{m} / \mathrm{z}): 557.2[\mathrm{M}+\mathrm{H}]^{+}$; HRMSAPCI $(\mathrm{m} / z):[\mathrm{M}+\mathrm{H}]^{+}$calcd for $\mathrm{C}_{32} \mathrm{H}_{37} \mathrm{~N}_{4} \mathrm{O}_{5}, 557.2759$; found 557.2755.

\section{$N^{1}-((2 S, 3 R)-3-H y d r o x y-4-((3-m e t h o x y b e n z y l) a m i n o)-1-p h e n y l b u t a n-2-y l)-N^{3}, 5-d i m e t h y l-N^{3}-$ ((4-methyloxazol-2-yl)methyl)isophthalamide (3n)}

Title compound was obtained from acid $7 \mathrm{~b}$ and isosteric amine $18 \mathrm{~b}$ following the procedure described for compound $\mathbf{2 f}$. ${ }^{1} \mathrm{H}$ NMR $\left(800 \mathrm{MHz}, \mathrm{CDCl}_{3}\right) \delta \mathbf{7 . 6 7}-7.47(\mathrm{~m}, 1 \mathrm{H}), 7.46-7.34$ (m, 1H), $7.34-7.08(\mathrm{~m}, 8 \mathrm{H}), 7.06-6.87(\mathrm{~m}, 2 \mathrm{H}), 6.84(\mathrm{~d}, \boldsymbol{J}=8.3 \mathrm{~Hz}, \mathbf{1 H}), 4.82(\mathrm{~s}, 1 \mathrm{H})$, $4.44(\mathrm{~s}, 1 \mathrm{H}), 4.41-4.32(\mathrm{~m}, \mathbf{1 H}), 3.96(\mathrm{~s}, 1 \mathrm{H}), 3.88(\mathrm{~d}, \boldsymbol{J}=12.0 \mathrm{~Hz}, 2 \mathrm{H}), 3.78(\mathrm{~s}, 3 \mathrm{H}), 3.17$ $-3.05(\mathrm{~m}, 3 \mathrm{H}), 3.05-2.89(\mathrm{~m}, 5 \mathrm{H}), 2.89-2.73(\mathrm{~m}, 2 \mathrm{H}), 2.35(\mathrm{~s}, 3 \mathrm{H}), 2.19(\mathrm{~s}, 3 \mathrm{H}) ;{ }^{13} \mathrm{C}$ NMR $\left(200 \mathrm{MHz}, \mathrm{CDCl}_{3}\right) \delta 171.1,167.5,159.9,159.3,139.0,137.8,136.6,135.6,135.1$, $134.3,130.7,129.8,129.5,129.3,128.5,126.6,122.9,121.2,114.4,113.9,70.3,55.3,54.0$, 52.9, 50.5, 36.2, 29.7, 21.2, 11.5. LRMS-ESI $(\boldsymbol{m} / \mathbf{z}): 571.3[\mathrm{M}+\mathrm{H}]^{+}$; HRMS-APCI $(\boldsymbol{m} / \mathbf{z}):[\mathrm{M}$ $+\mathrm{H}]^{+}$calcd for $\mathrm{C}_{33} \mathrm{H}_{39} \mathrm{~N}_{4} \mathrm{O}_{5}, 571.2915$; found 571.2921.

\section{$N^{1}$-((2S,3R)-3-Hydroxy-4-((3-methoxybenzyl)ammo)-1-phenylbutan-2-yl)- $N^{\beta}, 5$-dimethyl- $N^{\beta}$ - (1-(4-methyloxazol-2-yl)ethyl)isophthalamide (30)}

To a solution of carboxylic acid $24(42 \mathrm{mg}, 0.13 \mathrm{mmol})$ in $\mathrm{CH}_{2} \mathrm{Cl}_{2}(2 \mathrm{~mL})$ were added EDCI $\mathrm{HCl}(32 \mathrm{mg}, 0.16 \mathrm{mmol})$ and $\mathrm{HOBt} \cdot \mathrm{H}_{2} \mathrm{O}(22 \mathrm{mg}, 0.16 \mathrm{mmol})$ at $0{ }^{\circ} \mathrm{C}$ and the mixture was stirred for $10 \mathrm{~min}$. Amine $18 \mathrm{~b}(50 \mathrm{mg}, 0.16 \mathrm{mmol})$ in $\mathrm{CH}_{2} \mathrm{Cl}_{2}(1 \mathrm{~mL})$ and DIPEA $(30 \mu \mathrm{L}$, $0.16 \mathrm{mmol}$ ) were added at $0{ }^{\circ} \mathrm{C}$ and the resulting mixture was stirred at $23{ }^{\circ} \mathrm{C}$ for $12 \mathrm{~h}$. After this period, the reaction was quenched with saturated aqueous $\mathrm{NH}_{4} \mathrm{Cl}$ solution. The mixture was extracted with $\mathrm{CH}_{2} \mathrm{Cl}_{2}$, dried over anhydrous $\mathrm{Na}_{2} \mathrm{SO}_{4}$, filtered and concentrated under reduced pressure. The residue was purified by column chromatography over silica gel (3\% $\mathrm{MeOH} / \mathrm{CH}_{2} \mathrm{Cl}_{2}$ ) to afford inhibitor 30 (39 mg, 48\%). ${ }^{1} \mathrm{H}$ NMR (800 MHz, $\mathrm{CD}_{3} \mathrm{OD}$ ): $\delta$ 7.70-7.61 (m, 1H), 7.53-7.37 (m, 3H), 7.34 (t, $J=7.3 \mathrm{~Hz}, 1 \mathrm{H}), 7.30-7.21(\mathrm{~m}, 4 \mathrm{H}), 7.17(\mathrm{~m}$, 
1H), $7.10(\mathrm{~m}, 1 \mathrm{H}), 7.07$ (d, $J=6.5 \mathrm{~Hz}, 1 \mathrm{H}), 6.98(\mathrm{~d}, J=7.6 \mathrm{~Hz}, 1 \mathrm{H}), 5.95(\mathrm{~m}, 0.6 \mathrm{H}), 4.96$ (m, 0.4H), 4.28-4.19 (m, 3H), $3.96(\mathrm{~m}, 1 \mathrm{H}), 3.81(\mathrm{~s}, 3 \mathrm{H}), 3.38(\mathrm{~d}, J=12.5 \mathrm{~Hz}, 1 \mathrm{H}), 3.19$ (d, $J=12.0 \mathrm{~Hz}, 1 \mathrm{H}), 3.06(\mathrm{~m}, 1 \mathrm{H}), 2.89(\mathrm{~m}, 1 \mathrm{H}), 2.86-2.73(\mathrm{~m}, 3 \mathrm{H}), 2.42(\mathrm{~s}, 3 \mathrm{H}), 2.23-2.14$ (m, 3H), 1.74-1.56 (m, 3H); ${ }^{13} \mathrm{C}$ NMR (200 MHz, $\left.\mathrm{CD}_{3} \mathrm{OD}\right): \delta 171.4,168.8,160.3,139.1$, $138.2,136.3,135.9,135.7,135.5,134.2,132.0,130.3,129.9,129.1,129.0,128.7,128.1$, $126.2,122.6,121.8,115.2,114.9,69.2,54.6,54.4,50.8,49.6,48.1,48.0,35.8,32.3$, 19.8,14.9, 13.8, 9.8; LRMS-ESI $(\mathrm{m} / \mathrm{z}): 585[\mathrm{M}+\mathrm{H}]^{+}$; HRMS-ESI $(\mathrm{m} / \mathrm{z}):[\mathrm{M}+\mathrm{H}]^{+}$calcd for $\mathrm{C}_{34} \mathrm{H}_{41} \mathrm{~N}_{4} \mathrm{O}_{5}, 585.3072$; found 585.3068.

\section{(2S,3S)-2-(((2R,3S)-3-Amino-2-hydroxy-4-phenylbutyl)amino)-3-hydroxy-N- isobutylbutanamide (10a)}

Compound was synthesized from derivative $8 \mathbf{a}$ and epoxide 9 as reported. ${ }^{1} \mathrm{H}$ data are identical to those reported in literature. ${ }^{36}$

\section{(2S,3S)-2-(((2R,3S)-3-Amino-2-hydroxy-4-phenylbutyl)amino)-3-hydroxy- $N$ - isobutylhexanamide (10b)}

Compound was synthesized from derivative $8 \mathbf{b}$ and epoxide 9 as reported. ${ }^{1} \mathrm{H}$ data are identical to those reported in literature. ${ }^{36}$

\section{(E)-1-Methoxy-3-(prop-1-en-1-yl)benzene (12a)}

$n$-Butyllithium (1.6 M solution in $n$-hexane, $6.5 \mathrm{~mL}, 10.43 \mathrm{mmol}$ ) was added dropwise to a stirred suspension of ethyltriphenylphosphonium bromide ( $3.8 \mathrm{~g}, 10.28 \mathrm{mmol})$ in dry THF $\left(37 \mathrm{~mL}\right.$ ) at $-78{ }^{\circ} \mathrm{C}$ under argon atmosphere. The temperature of the reaction mixture was allowed to rise to $0{ }^{\circ} \mathrm{C}$ for $30 \mathrm{~min}$ and then the solution was cooled again to $-78{ }^{\circ} \mathrm{C}$.

Subsequently, a solution of 3-methoxybenzaldehyde 11a $(1.0 \mathrm{~g}, 7.35 \mathrm{mmol})$ in dry THF (10 $\mathrm{mL}$ ) was added over $30 \mathrm{~min}$. The reaction mixture was stirred for an additional $20 \mathrm{~min}$ at $-78{ }^{\circ} \mathrm{C}$ and then for $3 \mathrm{~h}$ at $25^{\circ} \mathrm{C}$. Water was added and the reaction mixture was extracted three times with EtOAc. The organic layers were dried over anhydrous sodium sulfate, filtered and concentrated under reduced pressure. The residue was purified by silica gel flash chromatography ( $n$-hexane-EtOAc 9:1) providing 1-methoxy-3-(prop-1-en-1-yl)benzene as $E / Z$ mixture (88\% yield). The $E / Z$ mixture of alkenes $(959 \mathrm{mg}, 6.41 \mathrm{mmol}$ ) was dissolved in chloroform (40 mL). Bis(acetonitrile)dichloropalladium (II) (30 mg) was added and the reaction mixture was stirred at $25^{\circ} \mathrm{C}$ for $72 \mathrm{~h}$. Then, solvent was evaporated, and the residue was purified by using a short silica gel path eluted with $n$-hexane-EtOAc 9:1 to afford 12a as a pale yellow oil (95\% yield). ${ }^{1} \mathrm{H}$ NMR $\left(300 \mathrm{MHz}, \mathrm{CDCl}_{3}\right) \delta 7.24(\mathrm{t}, J=7.9 \mathrm{~Hz}, 1 \mathrm{H}), 7.01-$ $6.85(\mathrm{~m}, 2 \mathrm{H}), 6.78(\mathrm{dd}, J=8.2,2.5 \mathrm{~Hz}, 1 \mathrm{H}), 6.50-6.35(\mathrm{~m}, 1 \mathrm{H}), 6.36-6.16(\mathrm{~m}, 1 \mathrm{H}), 3.83$ (s, $3 \mathrm{H}), 1.91(\mathrm{~d}, J=6.3 \mathrm{~Hz}, 3 \mathrm{H})$.

\section{(E)-1-Methoxy-3-(pent-1-en-1-yl)benzene (12b)}

Title compound was obtained following the procedure described for 12a. The residue was purified by silica gel flash chromatography ( $n$-hexane-EtOAc 9:1) to afford title compound as a dark yellow oil (69\% yield over two steps). ${ }^{1} \mathrm{H} \mathrm{NMR}\left(300 \mathrm{MHz}, \mathrm{CDCl}_{3}\right) \delta 7.33-7.18$ $(\mathrm{m}, 1 \mathrm{H}), 7.05-6.92(\mathrm{~m}, 2 \mathrm{H}), 6.88-6.74(\mathrm{~m}, 1 \mathrm{H}), 6.51-6.34(\mathrm{~m}, 1 \mathrm{H}), 6.35-6.18(\mathrm{~m}, 1 \mathrm{H})$, $3.84(\mathrm{~s}, 3 \mathrm{H}), 2.32-2.13(\mathrm{~m}, 2 \mathrm{H}), 1.63-1.43(\mathrm{~m}, 2 \mathrm{H}), 1.00(\mathrm{t}, J=7.3 \mathrm{~Hz}, 3 \mathrm{H})$. 


\section{(E)-Pent-1-en-1-ylbenzene (12c)}

Title compound was obtained following the procedure described for 12a. The residue was purified by silica gel flash chromatography ( $n$-hexane-EtOAc 15:1) to afford title compound as a dark yellow oil (81\% yield over 2 steps). ${ }^{1} \mathrm{H}$ NMR $\left(300 \mathrm{MHz}, \mathrm{CDCl}_{3}\right) \delta 7.45-7.26(\mathrm{~m}$, $4 \mathrm{H}), 7.25-7.14(\mathrm{~m}, 1 \mathrm{H}), 6.46-6.34(\mathrm{~m}, 1 \mathrm{H}), 6.33-6.16(\mathrm{~m}, 1 \mathrm{H}), 2.20(\mathrm{td}, J=7.6,0.8 \mathrm{~Hz}$, $2 \mathrm{H}), 1.61-1.40(\mathrm{~m}, 2 \mathrm{H}), 1.08-0.92(\mathrm{~m}, 3 \mathrm{H})$.

\section{(1S,2S)-1-(3-Methoxyphenyl)propane-1,2-diol (13a)}

Compound 12a (200 mg, $1.35 \mathrm{mmol}$ ) was dissolved in a 1:1 mixture of $t \mathrm{BuOH}$ and water $(20 \mathrm{~mL})$. Methanesulfonamide $(193 \mathrm{mg}, 2.02 \mathrm{mmol})$ and AD-mix- $\mathrm{a}(1.9 \mathrm{~g})$ were added in sequence and the reaction mixture was stirred at $25^{\circ} \mathrm{C}$ for $36 \mathrm{~h}$. The reaction was quenched with $\mathrm{Na}_{2} \mathrm{SO}_{3}$ and extracted three times with EtOAc. The organic layer was washed with brine, dried over anhydrous sodium sulfate, filtered and concentrated under reduced pressure. The residue was purified by silica gel flash chromatography ( $n$-hexane/EtOAc 1:1) providing title compound as a white amorphous solid (73\% yield). ${ }^{1} \mathrm{H} \mathrm{NMR}(300 \mathrm{MHz}$, $\left.\mathrm{CDCl}_{3}\right) \delta 7.32-7.16(\mathrm{~m}, 1 \mathrm{H}), 6.96-6.75(\mathrm{~m}, 3 \mathrm{H}), 4.40-4.23(\mathrm{~m}, 1 \mathrm{H}), 3.89-3.73(\mathrm{~m}$, $4 \mathrm{H}), 3.11-2.96(\mathrm{~m}, 2 \mathrm{H}), 2.80(\mathrm{br}, 1 \mathrm{H}), 1.04(\mathrm{~d}, J=6.3 \mathrm{~Hz}, 3 \mathrm{H}) ;{ }^{13} \mathrm{C} \mathrm{NMR}(75 \mathrm{MHz}$, $\left.\mathrm{CDCl}_{3}\right) \delta$ 159.6, 142.6, 129.4, 119.1, 113.3, 112.3, 79.2, 72.0, 55.1, 18.6.

\section{(1S,2S)-1-(3-Methoxyphenyl)pentane-1,2-diol (13b)}

Title compound was obtained following the procedure described for 13a. The residue was purified by silica gel flash chromatography ( $n$-hexane-EtOAc 1:1) to afford title compound as a dark yellow oil (68\% yield). ${ }^{1} \mathrm{H}$ NMR $\left(300 \mathrm{MHz}, \mathrm{CDCl}_{3}\right) \delta 7.29-7.12(\mathrm{~m}, 1 \mathrm{H}), 6.91-$ $6.70(\mathrm{~m}, 3 \mathrm{H}), 4.42-4.18(\mathrm{~m}, 1 \mathrm{H}), 3.78-3.65(\mathrm{~m}, 4 \mathrm{H}), 3.11-2.96(\mathrm{~m}, 2 \mathrm{H}), 2.87(\mathrm{br}, 1 \mathrm{H})$, $1.71-1.23(\mathrm{~m}, 4 \mathrm{H}), 0.98-0.75(\mathrm{~m}, 3 \mathrm{H})$.

\section{(1S,2S)-1-Phenylpentane-1,2-diol (13c)}

Title compound was obtained following the procedure described for 13a. The residue was purified by silica gel flash chromatography ( $n$-hexane-EtOAc 1:1) to afford title compound as a dark yellow oil (68\% yield). ${ }^{1} \mathrm{H}$ NMR $\left(300 \mathrm{MHz}, \mathrm{CDCl}_{3}\right) \delta 7.49-7.24(\mathrm{~m}, 5 \mathrm{H}), 4.44$ $(\mathrm{d}, J=6.8 \mathrm{~Hz}, 1 \mathrm{H}), 3.70$ (ddd, $J=8.3,6.9,3.5 \mathrm{~Hz}, 1 \mathrm{H}), 2.50(\mathrm{br}, 2 \mathrm{H}), 1.62-1.19(\mathrm{~m}, 4 \mathrm{H})$, $0.96-0.78(\mathrm{~m}, 3 \mathrm{H})$.

\section{(4S,5S)-4-Methyl-5-(3-methoxyphenyl)-1,3,2-dioxathiolane-2-oxide (14a)}

Diol 13a (300 mg, $1.65 \mathrm{mmol})$ was dissolved in triethylamine $(5 \mathrm{~mL})$ and cooled to $0{ }^{\circ} \mathrm{C}$ in an ice bath under an argon atmosphere. Thionyl chloride ( $144 \mu \mathrm{L}, 1.98 \mathrm{mmol})$ was added dropwise and the reaction mixture stirred at $0{ }^{\circ} \mathrm{C}$ for $50 \mathrm{~min}$ (monitored by TLC). After completion, ice-cold water $(20 \mathrm{~mL})$ was added and the mixture was extracted with $\mathrm{Et}_{2} \mathrm{O}$. The ethereal layer was washed with $10 \% \mathrm{HCl}$, saturated aqueous $\mathrm{NaHCO}_{3}$ and brine. The organic layer was dried over anhydrous sodium sulfate, filtered and evaporated under reduced pressure. The residue was purified by silica gel flash chromatography ( $n$-hexaneEtOAc 9:1) providing the compound as a dark yellow oil (79\% yield, mixture of diastereoisomers). ${ }^{1} \mathrm{H}$ NMR $\left(300 \mathrm{MHz}, \mathrm{CDCl}_{3}\right) \delta$ (1:1 diastereomeric mixture) 7.33 (td, $J=$ 
7.9, 3.1 Hz, 1H), $7.09-6.88(\mathrm{~m}, 3 \mathrm{H}), 5.41(\mathrm{~d}, J=9.1 \mathrm{~Hz}, 0.5 \mathrm{H}), 4.93-4.77(\mathrm{~m}, 1 \mathrm{H}), 4.39$ $(\mathrm{dq}, J=9.0,6.2 \mathrm{~Hz}, 0.5 \mathrm{H}), 3.83(\mathrm{~s}, 3 \mathrm{H}), 1.60(\mathrm{t}, J=10.4 \mathrm{~Hz}, 1.5 \mathrm{H}), 1.52-1.43(\mathrm{~m}, 1.5 \mathrm{H})$.

(4S,5S)-4-Propyl-5-(3-methoxyphenyl)-1,3,2-dioxathiolane-2-oxide (14b)

Title compound was obtained following the procedure described for $\mathbf{1 4 a}$. The residue was purified by silica gel flash chromatography ( $n$-hexane-EtOAc 9:1) to afford title compound as a brown oil (66\% yield). ${ }^{1} \mathrm{H}$ NMR $\left(300 \mathrm{MHz}, \mathrm{CDCl}_{3}\right) \delta(1: 1$ diastereomeric mixture) $7.32(\mathrm{td}, J=7.8,3.0 \mathrm{~Hz}, 1 \mathrm{H}), 6.96(\mathrm{ddd}, J=13.3,9.2,5.9 \mathrm{~Hz}, 3 \mathrm{H}), 5.45(\mathrm{~d}, J=9.0 \mathrm{~Hz}$, $0.5 \mathrm{H}), 4.88(\mathrm{~d}, J=9.6 \mathrm{~Hz}, 0.5 \mathrm{H}), 4.74(\mathrm{dt}, J=9.6,6.0 \mathrm{~Hz}, 0.5 \mathrm{H}), 4.31(\mathrm{td}, J=8.8,3.7 \mathrm{~Hz}$, $0.5 \mathrm{H}), 3.81(\mathrm{~s}, 3 \mathrm{H}), 2.00-1.32(\mathrm{~m}, 4 \mathrm{H}), 0.92(\mathrm{td}, J=7.2,2.1 \mathrm{~Hz}, 3 \mathrm{H})$.

\section{(4S,5S)-4-Propyl-5-phenyl-1,3,2-dioxathiolane-2-oxide (14c)}

Title compound was obtained following the procedure described for $\mathbf{1 4 a}$. The residue was purified by silica gel flash chromatography ( $\boldsymbol{n}$-hexane-EtOAc 9:1) to afford title compound as a brown oil (54\% yield). ${ }^{1} \mathrm{H}$ NMR $\left(300 \mathrm{MHz}, \mathrm{CDCl}_{3}\right) \delta(1: 1$ diastereomeric mixture) $7.63-7.33(\mathrm{~m}, 5 \mathrm{H}), 5.49(\mathrm{~d}, \boldsymbol{J}=9.1 \mathrm{~Hz}, 0.5 \mathrm{H}), 4.91(\mathrm{~d}, \boldsymbol{J}=9.6 \mathrm{~Hz}, 0.5 \mathrm{H}), 4.85-4.68(\mathrm{~m}$, $0.5 \mathrm{H}), 4.44-4.22(\mathrm{~m}, 0.5 \mathrm{H}), 2.01-1.29(\mathrm{~m}, 4 \mathrm{H}), 1.08-0.82(\mathrm{~m}, 3 \mathrm{H})$.

\section{(1R,2S)-1-Azido-1-(3-methoxyphenyl)propan-2-ol (15a)}

To a stirred solution of cyclic sulfite 14a $(150 \mathrm{mg}, 0.66 \mathrm{mmol})$ in DMF $(5 \mathrm{~mL})$ was added sodium azide ( $171 \mathrm{mg}, 263 \mathrm{mmol})$. The reaction flask was then heated to $80 \mathrm{C}$ for $8 \mathrm{~h}$. After completion, the reaction mixture was poured in $25 \mathrm{~mL}$ of water, and then extracted three times with ether. The combined organic layers were washed with brine, dried over anhydrous sodium sulfate, filtered and concentrated under reduced pressure. The crude azidoalcohol was then purified by silica gel flash chromatography ( $\boldsymbol{n}$-hexane-EtOAc 9:1) to provide the title compound as a light yellow oil (88\% yield). ${ }^{1} \mathrm{H}$ NMR $\left(300 \mathrm{MHz}, \mathrm{CDCl}_{3}\right) \delta$ $7.41-7.23(\mathrm{~m}, 1 \mathrm{H}), 6.98-6.81(\mathrm{~m}, 3 \mathrm{H}), 4.43(\mathrm{~d}, \boldsymbol{J}=5.7 \mathrm{~Hz}, \mathbf{1 H}), 4.06-3.85(\mathrm{~m}, 1 \mathrm{H}), 3.81$ (s, 3H), 2.03 (br, 1H), 1.17 (d, J = 6.3 Hz, 3H).

\section{(1R,2S)-1-Azido-1-(3-methoxyphenyl)pentan-2-ol (15b)}

Title compound was obtained following the procedure described for 15a. The residue was purified by silica gel flash chromatography ( $n$-hexane-EtOAc 9:1) to afford title compound as a brown oil (74\% yield). ${ }^{1} \mathrm{H}$ NMR $\left(300 \mathrm{MHz}, \mathrm{CDCl}_{3}\right) \delta 7.42-7.23(\mathrm{~m}, 2 \mathrm{H}), 7.04-6.83$ $(\mathrm{m}, 2 \mathrm{H}), 4.45(\mathrm{~d}, J=5.8 \mathrm{~Hz}, 1 \mathrm{H}), 3.93-3.71(\mathrm{~m}, 4 \mathrm{H}), 1.77-1.20(\mathrm{~m}, 5 \mathrm{H}), 0.91(\mathrm{t}, J=6.5$ $\mathrm{Hz}, 3 \mathrm{H})$.

\section{(1R,2S)-1-Azido-1-phenylpentan-2-ol (15c)}

Title compound was obtained following the procedure described for 15a. The residue was purified by silica gel flash chromatography ( $n$-hexane-EtOAc 9:1) to afford title compound as a brown oil (74\% yield). ${ }^{1} \mathrm{H}$ NMR $\left(300 \mathrm{MHz}, \mathrm{CDCl}_{3}\right) \delta 7.58-7.29(\mathrm{~m}, 4 \mathrm{H}), 4.48(\mathrm{~d}, J=$ $5.7 \mathrm{~Hz}, 1 \mathrm{H}), 3.79(\mathrm{~d}, J=5.7 \mathrm{~Hz}, 1 \mathrm{H}), 1.76-1.17(\mathrm{~m}, 5 \mathrm{H}), 1.06-0.83(\mathrm{~m}, 3 \mathrm{H})$. 


\section{(1R,2S)-1-Ammo-1-(3-methoxyphenyl)propan-2-ol (16a)}

To a solution of $15 \mathrm{a}(120 \mathrm{mg}, 0.58 \mathrm{mmol})$ and di-tert-butyldicarbonate $(164 \mathrm{mg}, 0.75 \mathrm{mmol})$ in EtOAc $(5 \mathrm{~mL}), 10 \% \mathrm{Pd} / \mathrm{C}(15 \mathrm{mg})$ was added and the reaction mixture was stirred at $25{ }^{\circ} \mathrm{C}$ under hydrogen atmosphere for $16 \mathrm{~h}$. The reaction mixture was then filtered through a celite plug. The residue containing tert-butyl ((1R,2S)-2-hydroxy-1-(4methoxyphenyl)propyl)carbamate ${ }^{1} \mathrm{H} \mathrm{NMR}\left(300 \mathrm{MHz}, \mathrm{CDCl}_{3}\right) \delta 7.26-7.20(\mathrm{~m}, 1 \mathrm{H}), 6.85-$ $6.75(\mathrm{~m}, 3 \mathrm{H}), 5.51$ (br, 1H), $4.56(\mathrm{br}, 1 \mathrm{H}), 4.10-3.96(\mathrm{~m}, 1 \mathrm{H}), 3.76$ (s, 3H), 2.31 (d, J = 6.6 $\mathrm{Hz}, \mathbf{1 H}), 1.39$ (s, 9H), $1.05(\mathrm{~d}, \boldsymbol{J}=6.6 \mathrm{~Hz}, 3 \mathrm{H})$ was submitted to the following step without further purification. The compound was dissolved in $\mathrm{CH}_{2} \mathrm{Cl}_{2}(2 \mathrm{~mL})$ and TFA $(300 \mu \mathrm{L})$ was added. The reaction mixture was stirred at $25^{\circ} \mathrm{C}$ for $2 \mathrm{~h}$, then solvents evaporated. $\mathrm{CH}_{2} \mathrm{Cl}_{2}$ $(3 \mathrm{~mL})$ was added to the residue and evaporated under reduced pressure. This operation was repeated additional two times. The residue was then taken up in $\mathrm{CH}_{2} \mathrm{Cl}_{2}$ and saturated aqueous $\mathrm{NaHCO}_{3}(1 \mathrm{~mL})$ was added. The organic layer was dried over anhydrous sodium sulfate, filtered and concentrated under reduced pressure to afford desired aminoalcohol as a white amorphous solid ( $86 \%$ yield, 2 steps).

\section{(1R,2S)-1-Ammo-1-(3-methoxyphenyl)pentan-2-ol (16b)}

Title compound was obtained following the procedure described for 16a to afford title compound as a white amorphous solid (66\% yield, 2 steps). tert-Butyl ((1R,2S)-2hydroxy-1-(3-methoxyphenyl)pentyl)carbamate ${ }^{1} \mathrm{H} \mathrm{NMR}\left(300 \mathrm{MHz}, \mathrm{CDCl}_{3}\right) \delta 7.23(\mathrm{t}, J=$ $7.8 \mathrm{~Hz}, 1 \mathrm{H}), 7.01-6.74(\mathrm{~m}, 3 \mathrm{H}), 5.56(\mathrm{br}, 1 \mathrm{H}), 4.60(\mathrm{br}, 1 \mathrm{H}), 3.95-3.63(\mathrm{~m}, 4 \mathrm{H}), 2.11-$ $1.85(\mathrm{~m}, 1 \mathrm{H}), 1.67-1.02(\mathrm{~m}, 13 \mathrm{H}), 0.86(\mathrm{t}, J=7.0 \mathrm{~Hz}, 3 \mathrm{H})$.

\section{(1R,2S)-1-Amino-1-phenylpentan-2-ol (16c)}

Title compound was obtained following the procedure described for 16a. to afford title compound as a white amorphous solid (66\% yield over two steps). tert-Butyl ((1R,2S)-2hydroxy-1-phenylpentyl)carbamate ${ }^{1} \mathrm{H} \mathrm{NMR}\left(300 \mathrm{MHz}, \mathrm{CDCl}_{3}\right) \delta 7.51-7.19(\mathrm{~m}, 5 \mathrm{H})$, 5.44 (br, 1H), 4.63 (br, 1H), 3.88 (d, $J=8.8 \mathrm{~Hz}, 1 \mathrm{H}), 1.72-1.02(\mathrm{~m}, 14 \mathrm{H}), 0.88$ (t, $J=7.1$ $\mathrm{Hz}, 3 \mathrm{H})$.

\section{(tert-Butyl ((2S,3R)-3-hydroxy-4-(((1R,2S)-2-hydroxy-1-(3-methoxyphenyl)propyl)amino)-1- phenylbutan-2-yl)carbamate (17a)}

Compound 16a $(0.565 \mathrm{mmol})$ was dissolved in $\boldsymbol{i}$-PrOH $(7 \mathrm{~mL})$ and $9(74 \mathrm{mg}, 0.283 \mathrm{mmol})$ was added. The reaction mixture was stirred at $80{ }^{\circ} \mathrm{C}$ for $14 \mathrm{~h}$. The solvent was evaporated under reduced pressure and the residue was purified by silica gel flash chromatography $\left(\mathrm{CH}_{2} \mathrm{Cl}_{2} / \mathrm{MeOH}\right.$ 100:0 to 98:2) providing title compound as an amorphous white solid (65\% yield). ${ }^{1} \mathrm{H}$ NMR (300 MHz, $\left.\mathrm{CDCl}_{3}\right) \delta 7.43-7.10(\mathrm{~m}, 5 \mathrm{H}), 7.00-6.74(\mathrm{~m}, 3 \mathrm{H}), 4.85(\mathrm{~d}, \boldsymbol{J}=$ $8.9 \mathrm{~Hz}, 1 \mathrm{H}), 4.38-4.23(\mathrm{~m}, 1 \mathrm{H}), 4.12-3.95(\mathrm{~m}, 2 \mathrm{H}), 3.93-3.75(\mathrm{~m}, 4 \mathrm{H}), 3.75-3.61(\mathrm{~m}$, $5 \mathrm{H}), 3.62-3.48(\mathrm{~m}, 2 \mathrm{H}), 3.47-3.15(\mathrm{~m}, 1 \mathrm{H}), 3.04-2.48(\mathrm{~m}, 6 \mathrm{H}), 1.48-1.12(\mathrm{~m}, 9 \mathrm{H})$, $1.05(\mathrm{~d}, \boldsymbol{J}=6.2 \mathrm{~Hz}, 3 \mathrm{H})$. 


\section{tert-Butyl ((2S,3R)-3-hydroxy-4-(((1R,2S)-2-hydroxy-1-(3-methoxyphenyl)pentyl)amino)-1- phenylbutan-2-yl)carbamate (17b)}

Title compound was obtained following the procedure described for 17a. The residue was purified by silica gel flash chromatography $\left(\mathrm{CH}_{2} \mathrm{Cl}_{2} / \mathrm{MeOH}\right.$ 100:0 to 98:2) to afford title compound as a pale yellow oil (71\% yield). $1 \mathrm{H} \mathrm{NMR}{ }^{1} \mathrm{H}$ NMR $\left(300 \mathrm{MHz}, \mathrm{CDCl}_{3}\right) \delta 7.39$ $7.07(\mathrm{~m}, 5 \mathrm{H}), 6.95-6.72(\mathrm{~m}, 3 \mathrm{H}), 4.74(\mathrm{~d}, \boldsymbol{J}=8.8 \mathrm{~Hz}, 1 \mathrm{H}), 3.90-3.74(\mathrm{~m}, 5 \mathrm{H}), 3.66-3.36$ (m, 3H), $3.13-2.74(\mathrm{~m}, 6 \mathrm{H}), 2.74-2.51(\mathrm{~m}, 2 \mathrm{H}), 1.55-1.12(\mathrm{~m}, 13 \mathrm{H}), 0.87$ (t, $\boldsymbol{J}=7.0 \mathrm{~Hz}$, $3 \mathrm{H})$.

\section{tert-Butyl ((2S,3R)-3-hydroxy-4-(((1R,2S)-2-hydroxy-1-phenylpentyl)amino)-1- phenylbutan-2-yl)carbamate (17c)}

Title compound was obtained following the procedure described for 17a. The residue was purified by silica gel flash chromatography $\left(\mathrm{CH}_{2} \mathrm{Cl}_{2} / \mathrm{MeOH}\right.$ 100:0 to 98:2) to afford title compound as a pale yellow oil (71\% yield). ${ }^{1} \mathrm{H}$ NMR $\left(300 \mathrm{MHz}, \mathrm{CDCl}_{3}\right) \delta 7.50-7.09(\mathrm{~m}$, $10 \mathrm{H}), 4.77(\mathrm{~d}, \boldsymbol{J}=8.8 \mathrm{~Hz}, 1 \mathrm{H}), 3.95-3.78(\mathrm{~m}, 2 \mathrm{H}), 3.78-3.33(\mathrm{~m}, 2 \mathrm{H}), 3.31-3.00(\mathrm{~m}$, $2 \mathrm{H}), 2.98-2.74(\mathrm{~m}, 2 \mathrm{H}), 2.76-2.51(\mathrm{~m}, 2 \mathrm{H}), 1.65-1.06(\mathrm{~m}, 13 \mathrm{H}), 0.86(\mathrm{t}, \boldsymbol{J}=7.0 \mathrm{~Hz}$, $3 \mathrm{H})$.

\section{tert-Butyl methyl(1-(4-methyloxazol-2-yl)ethyl)carbamate (22)}

A solution of $21(110 \mathrm{mg}, 0.486 \mathrm{mmol})$ in diethyl ether $(5 \mathrm{~mL})$ was cooled to $-78{ }^{\circ} \mathrm{C}$ and treated with TMEDA ( $95 \mu \mathrm{L}, 0.63 \mathrm{mmol}$ ), followed by $s$-BuLi ( $45 \mu \mathrm{L}, 0.63 \mathrm{mmol})$ dropwise. The mixture was stirred for $30 \mathrm{~min}$ at $-78{ }^{\circ} \mathrm{C}$ and treated with a solution of iodomethane (60 $\mu \mathrm{L}, 0.97 \mathrm{mmol}$ ) in $1 \mathrm{~mL}$ of diethyl ether and then slowly warmed to room temperature and stirred for $8 \mathrm{~h}$. The mixture was diluted with $6 \mathrm{~mL}$ of water and extracted with ether $(2 \times 20$ $\mathrm{mL}$ ) and washed with saturated aqueous $\mathrm{NH}_{4} \mathrm{Cl}$ solution. The combined extracts were dried over $\mathrm{Na}_{2} \mathrm{SO}_{4}$, filtered and concentrated under reduced pressure to give a crude product which was purified by column chromatography over silica gel to afford $22(64 \mathrm{mg}, 55 \%)$ as a colorless oil and $28 \mathrm{mg}$ of starting material was recovered. ${ }^{1} \mathrm{H}$ NMR $\left(400 \mathrm{MHz}, \mathrm{CDCl}_{3}\right): \delta$ 7.30 (q, $\boldsymbol{J}=4.0 \mathrm{~Hz}, 1 \mathrm{H}), 5.54$ (m, 0.6H), 5.20 (m, 0.4H), 2.67 (brs, $3 \mathrm{H}), 2.15$ (d, $\boldsymbol{J}=1.2 \mathrm{~Hz}$, $3 \mathrm{H}), 1.54(\mathrm{~d}, \boldsymbol{J}=7.0 \mathrm{~Hz}, 3 \mathrm{H}), 1.46(\mathrm{~s}, 9 \mathrm{H})$. LRMS-ESI $(\boldsymbol{m} / \boldsymbol{z}): 241[\mathrm{M}+\mathrm{H}]^{+}$.

\section{3-Methyl-5-(methyl(1-(4-methyloxazol-2-yl)ethyl)carbamoyl)benzoic acid (24)}

Methyl 3-methyl-5-(methyl(1-(4-methyloxazol-2-yl)ethyl)carbamoyl)benzoate. To a stirred solution of $22(64 \mathrm{mg}, 0.26 \mathrm{mmol})$ in dichloromethane $(3 \mathrm{~mL})$ was added TFA $(1 \mathrm{~mL})$ at $0{ }^{\circ} \mathrm{C}$ under argon atmosphere and the mixture was stirred at $23^{\circ} \mathrm{C}$ for $2 \mathrm{~h}$. Upon completion, trifluoroacetic acid and $\mathrm{CH}_{2} \mathrm{Cl}_{2}$ were removed under reduced pressure, the resulting residue was dissolved in ethyl acetate and washed with saturated aqueous $\mathrm{NaHCO}_{3}$ solution. The organic layer was dried over anhydrous $\mathrm{Na}_{2} \mathrm{SO}_{4}$, filtered and concentrated under reduced pressure to afford amine derivative $(40 \mathrm{mg}$ ) which used for next step without further purification.

To a solution above $N$-methyl-1-(4-methyloxazol-2-yl)ethan-1-amine (40 $\mathrm{mg}, 0.28 \mathrm{mmol}$ ) and 3-(methoxycarbonyl)-5-methylbenzoic acid $\mathbf{2 3}(66 \mathrm{mg}, 0.34 \mathrm{mmol})$ in $\mathrm{CH}_{2} \mathrm{Cl}_{2}(4 \mathrm{~mL})$ at $23{ }^{\circ} \mathrm{C}$ was added $\mathrm{EDCI}$. $\mathrm{HCl}(109 \mathrm{mg}, 0.57 \mathrm{mmol}), \mathrm{HOBt} \cdot \mathrm{H}_{2} \mathrm{O}(74 \mathrm{mg}, 0.57 \mathrm{mmol})$ and 
$N, N$-DIPEA $(150 \mu \mathrm{L}, 0.85 \mathrm{mmol})$. The resulting mixture was stirred at $23{ }^{\circ} \mathrm{C}$ for $12 \mathrm{~h}$. After this period, the reaction was quenched with saturated aqueous $\mathrm{NaHCO}_{3}$ solution. The mixture was extracted with EtOAc, dried over anhydrous $\mathrm{Na}_{2} \mathrm{SO}_{4}$, filtered and concentrated under reduced pressure. The residue was purified by silica gel column chromatography (40\% EtOAc/hexanes) to provide the corresponding amide derivative Methyl 3-methyl-5(methyl(1-(4-methyloxazol-2-yl)ethyl)carbamoyl)benzoate (60 mg, $66 \%$ over 2 steps). ${ }^{1} \mathrm{H}$ NMR (400 MHz, $\left.\mathrm{CDCl}_{3}\right) \delta 8.02-7.84(\mathrm{~m}, 2 \mathrm{H}), 7.47(\mathrm{~m}, 1 \mathrm{H}), 7.36(\mathrm{~m}, 1 \mathrm{H}), 6.05(\mathrm{~m}, 0.6 \mathrm{H})$, $4.96(\mathrm{~m}, 0.4 \mathrm{H}), 3.88(\mathrm{~s}, 3 \mathrm{H}), 2.86(\mathrm{~s}, 1.4 \mathrm{H}), 2.73(1.6 \mathrm{H}), 2.39(\mathrm{~s}, 3 \mathrm{H}), 2.14(\mathrm{~s}, 3 \mathrm{H}), 1.68-$ $1.54(\mathrm{~m}, 3 \mathrm{H}) .{ }^{13} \mathrm{C}$ NMR $\left(100 \mathrm{MHz}, \mathrm{CDCl}_{3}\right) \delta 171.0,170.5,166.4,162.3,161.7,139.0$, $138.8,136.2,136.1,135.0,134.9,132.1,131.7,131.3,130.3,130.1,125.1,124.8,52.2$, 46.9, 36.5, 32.5, 28.0, 24.6, 21.1, 16.2, 15.0, 11.3. LRMS-ESI $(\mathrm{m} / \mathrm{z}): 317[\mathrm{M}+\mathrm{H}]^{+}$.

To a solution of this latter ( $48 \mathrm{mg}, 0.15 \mathrm{mmol})$ in a mixture of water $(1 \mathrm{~mL})$ and THF ( $2 \mathrm{~mL})$ at $0{ }^{\circ} \mathrm{C}$ was added $\mathrm{LiOH} \bullet \mathrm{H}_{2} \mathrm{O}(19 \mathrm{mg}, 0.45 \mathrm{mmol})$. The resulting mixture was stirred for at $23{ }^{\circ} \mathrm{C}$ for $8 \mathrm{~h}$. Upon completion, the solvent was removed under reduced pressure, and the resulting mixture was diluted with $\mathrm{H}_{2} \mathrm{O}$ and washed with diethyl ether. The aqueous layer was acidified with aqueous $1 \mathrm{~N} \mathrm{HCl}$ and extracted with ethyl acetate $(3 \times 10 \mathrm{~mL})$. The combined organic fractions were dried over anhydrous $\mathrm{Na}_{2} \mathrm{SO}_{4}$ and concentrated in vacuo to furnish carboxylic acid $24(42 \mathrm{mg}, 92 \%) .{ }^{1} \mathrm{H} \mathrm{NMR}\left(400 \mathrm{MHz}, \mathrm{CDCl}_{3}\right): \delta 10.17$ (brs, $\left.1 \mathrm{H}\right)$, 8.05-7.89 (m, 2H), $7.51(\mathrm{~m}, 1 \mathrm{H}), 7.38(\mathrm{~s}, 1 \mathrm{H}), 6.07(\mathrm{~m}, 0.6 \mathrm{H}), 5.04(\mathrm{~m}, 0.4 \mathrm{H}), 2.91(\mathrm{~s}$, 1.3H), 2.79 (s, 1.7H), 2.40 (s, 3H), 2.17 (s, 3H), 1.73-1.57 (m, 3H); ${ }^{13} \mathrm{C}$ NMR (100 MHz, $\left.\mathrm{CDCl}_{3}\right): \delta 176.6,171.2,170.8,169.9,162.5,161.8,139.1,138.8,136.3,136.2,135.9,135.2$, 135.0, 132.6, 132.2, 131.2, 130.1, 129.9, 125.7, 125.3, 52.4, 47.2, 32.8, 29.58, 28.2, 21.1, 16.1, 14.9, 11.1. LRMS-ESI $(\mathrm{m} / \mathrm{z}): 303[\mathrm{M}+\mathrm{H}]^{+}$.

\section{Supplementary Material}

Refer to Web version on PubMed Central for supplementary material.

\section{Acknowledgments}

Financial support by the National Institutes of Health and Purdue University is gratefully acknowledged. A.D.M also wishes to acknowledge partial support from the Walther Cancer Foundation. NMR, mass spectrometry and protein crystallization were supported in part by the Purdue Center for Cancer Research Shared Resources, which are supported by NIH grant (P30 CA023168). Use of the Advanced Photon Source, an Office of Science User Facility operated for the U.S. Department of Energy (DOE) Office of Science by Argonne National Laboratory, was supported by the U.S. DOE under Contract No. DE-AC02-06CH11357. Use of the LS-CAT Sector 21 was supported by the Michigan Economic Development Corporation and the Michigan Technology Tri-Corridor (Grant 085P1000817).

\section{Abbreviations}

BACE1

BACE2

DPP-4

FDA

SAR beta-site amyloid precursor protein cleaving enzyme 1

beta-site amyloid precursor protein cleaving enzyme 2

dipeptidyl peptidase 4

Food and Drug Administration

structure-activity relationships 
SGLT2 sodium-glucose linked transporter 2

\section{References:}

[1]. Kahn SE, Cooper ME, Del Prato S, Lancet 2014, 383, 1068-1083. [PubMed: 24315620]

[2]. Zimmet P, Alberti KG, Shaw J, Nature 2001, 414, 782-787. [PubMed: 11742409]

[3]. Stumvoll M, Goldstein BJ, van Haeften TW, Lancet 2005, 365, 1333-1346. [PubMed: 15823385]

[4]. IDF Diabetes Atlas Seventh Edition. Available at: http://www.diabetesatlas.org/kevmessages.html. (Accessed: 1th April 2016).

[5]. Li MZ, Su L, Liang BY, Tan JJ, Chen Q, Long JX, Xie JJ, Wu GL, Yan Y, Guo XJ, Gu L, int. J. Endocrinol 2013, 2013, 753150. [PubMed: 24288530]

[6]. Liu L, Zhou C, Du H, Zhang K, Huang D, Wu J, Sci. Rep 2014, 4, 4835. [PubMed: 24824525]

[7]. Chaudhury A, Duvoor C, Reddy Dendi VS, Kraleti S, Chada A, Ravilla R, Marco A, Shekhawat NS, Montales MT, Kuriakose K, Sasapu A, Beebe A, Patil N, Musham CK, Lohani GP, Mirza W, Front. Endocrinol. (Lausanne) 2017, 8, 6. [PubMed: 28167928]

[8]. Standards of medical care in diabetes--2014. Diabetes Care 2014, 37 Suppl 1, S14-80. [PubMed: 24357209]

[9]. Standards of Medical Care in Diabetes-2016: Summary of Revisions. Diabetes Care 2016, 39 Suppl 1, S4-5. [PubMed: 26696680]

[10]. Eckerle Mize DL, Salehi M, Curr. Diabetes Rep 2013, 13, 307-318.

[11]. Ferrannini E, DeFronzo RA, Eur. Heart J 2015, 36, 2288-2296. [PubMed: 26063450]

[12]. Chamberlain JJ, Rhinehart AS, Shaefer CF Jr., Neuman A, Ann. intern. Med 2016, 164, 542-552. [PubMed: 26928912]

[13]. Verma S, Mazer CD, Fitchett D, Inzucchi SE, Pfarr E, George JT, Zinman B, Diabetologia 2018, 61, 1712-1723. [PubMed: 29777264]

[14]. Esterhazy D, Stutzer I, Wang H, Rechsteiner MP, Beauchamp J, Dobeli H, Hilpert H, Matile H, Prummer M, Schmidt A, Lieske N, Boehm B, Marselli L, Bosco D, Kerr-Conte J, Aebersold R, Spinas GA, Moch H, Migliorini C, Stoffel M, Cell Metab. 2011, 14, 365-377. [PubMed: 21907142]

[15]. Alcarraz-Vizan G, Castano C, Visa M, Montane J, Servitja JM, Novials A, Cell Mol. Life Sci 2017, 74, 2827-2838. [PubMed: 28337562]

[16]. Altirriba J, Gasa R, Casas S, Ramirez-Bajo MJ, Ros S, Gutierrez-Dalmau A, de Villa MCR, Barbera A, Gomis R, Diabetologia 2010, 53, 1406-1414. [PubMed: 20386877]

[17]. Akpinar P, Kuwajima S, Krutzfeldt J, Stoffel M, Cell Metab. 2005, 2, 385-397. [PubMed: 16330324]

[18]. Southan C, Expert Opin. Ther Pat 2013, 23, 649-663. [PubMed: 23506624]

[19]. Lin X, Koelsch G, Wu S, Downs D, Dashti A, Tang J, Proc. Natl. Acad. Sci. U. S. A 2000, 97, 1456-1460. [PubMed: 10677483]

[20]. Turner RT 3rd, Loy JA, Nguyen C, Devasamudram T, Ghosh AK, Koelsch G, Tang J, Biochemistry 2002, 41, 8742-8746. [PubMed: 12093293]

[21]. Turner RT 3rd, Koelsch G, Hong L, Castanheira P, Ermolieff J, Ghosh AK, Tang J, Biochemistry 2001, 40, 10001-10006. [PubMed: 11513577]

[22]. Voytyuk I, Mueller SA, Herber J, Snellinx A, Moechars D, van Loo G, Lichtenthaler SF, De Strooper B, Life Sci. All 2018, 1, e201800026.

[23]. Rulifson IC, Cao P, Miao L, Kopecky D, Huang L, White RD, Samayoa K, Gardner J, Wu X, Chen K, Tsuruda T, Homann O, Baribault H, Yamane H, Carlson T, Wiltzius J, Li Y, PLoS One 2016, 11, e0147254. [PubMed: 26840340]

[24]. Kamenetz F, Tomita T, Hsieh H, Seabrook G, Borchelt D, Iwatsubo T, Sisodia S, Malinow R, Neuron 2003, 37, 925-937. [PubMed: 12670422]

[25]. Kobayashi D, Zeller M, Cole T, Buttini M, McConlogue L, Sinha S, Freedman S, Morris RG, Chen KS, Neurobiol. Aging 2008, 29, 861-873. [PubMed: 17331621] 
[26]. Willem M, Garratt AN, Novak B, Citron M, Kaufmann S, Rittger A, DeStrooper B, Saftig P, Birchmeier C, Haass C, Science 2006, 314, 664-666. [PubMed: 16990514]

[27]. Hu X, Zhou X, He W, Yang J, Xiong W, Wong P, Wilson CG, Yan R, Neurosci J 2010, 30, 88198829.

[28]. Harrison SM, Harper AJ, Hawkins J, Duddy G, Grau E, Pugh PL, Winter PH, Shilliam CS, Hughes ZA, Dawson LA, Gonzalez MI, Upton N, Pangalos MN, Dingwall C, Mol. Cell. Neurosci 2003, 24, 646-655. [PubMed: 14664815]

[29]. Diment S, Leech MS, Stahl PD, J. Biol. Chem 1988, 263, 6901-6907. [PubMed: 3360812]

[30]. Liaudet-Coopman E, Beaujouin M, Derocq D, Garcia M, Glondu-Lassis M, Laurent-Matha V, Prebois C, Rochefort H, Vignon F, Cancer Lett. 2006, 237, 167-179. [PubMed: 16046058]

[31]. Steinfeld R, Reinhardt K, Schreiber K, Hillebrand M, Kraetzner R, Bruck W, Saftig P, Gartner J, Am. J. Hum. Genet 2006, 78, 988-998. [PubMed: 16685649]

[32]. Benes P, Vetvicka V, Fusek M, Crit. Rev. Oncol. Hematol 2008, 68, 12-28. [PubMed: 18396408]

[33]. Kennedy ME, Stamford AW, Chen X, Cox K, Cumming JN, Dockendorf MF, Egan M, Ereshefsky L, Hodgson RA, Hyde LA, Jhee S, Kleijn HJ, Kuvelkar R, Li W, Mattson BA, Mei H, Palcza J, Scott JD, Tanen M, Troyer MD, Tseng JL, Stone JA, Parker EM, Forman MS, Sci. Transl. Med 2016, 8, 363ra150.

[34]. Neumann U, Rueeger H, Machauer R, Veenstra SJ, Lueoend RM, Tintelnot-Blomley M, Laue G, Beltz K, Vogg B, Schmid P, Frieauff W, Shimshek DR, Staufenbiel M, Jacobson LH, Mol. Neurodegener 2015, 10, 44. [PubMed: 26336937]

[35]. Beauchamp J; Bernardeau A;, Hilpert H;, Migliorini C;, Riboulet W; Wang H, 2- Aminodihydro [1,3]-thiazines as BACE2 inhibitors for the treatment of diabetes, WO2011029803A1. 2011.

[36]. Ghosh AK, Reddy BS, Yen YC, Cardenas E, Rao KV, Downs D, Huang X, Tang J, Mesecar AD, Chem. Sci 2016, 7, 3117-3122. [PubMed: 27347366]

[37]. Ghosh AK; Anderson DD; Mitsuya H, Burger's Medicinal Chemistry, Drug Discovery and Development 2010; Vol. 7.

[38]. Ghosh AK, Chapsal BD, Mitsuya H, Methods Prins. Med. Chem 2010; Vol. 45.

[39]. Ghosh AK, Kumaragurubaran N, Hong L, Kulkarni S, Xu X, Miller HB, Reddy DS, Weerasena V, Turner R, Chang W, Koelsch G, Tang J, Bioorg. Med. Chem. Lett 2008, 18, 1031-1036. [PubMed: 18180160]

[40]. Chang WP, Huang X, Downs D, Cirrito JR, Koelsch G, Holtzman DM, Ghosh AK, Tang J, F.A.S.E.B. J 2011, 25, 775-784.

[41]. Ostermann N, Eder J, Eidhoff U, Zink F, Hassiepen U, Worpenberg S, Maibaum J, Simic O, Hommel U, Gerhartz B, J. Mol. Biol 2006, 355, 249-261. [PubMed: 16305800]

[42]. Stutzer I, Selevsek N, Esterhazy D, Schmidt A, Aebersold R, Stoffel M, J. Biol. Chem 2013, 288, 10536-10547. [PubMed: 23430253]

[43]. Ghosh AK, Venkateswara Rao K, Yadav ND, Anderson DD, Gavande N, Huang X, Terzyan S, Tang J, J. Med. Chem 2012, 55, 9195-9207. [PubMed: 22954357]

[44]. Yang W, Cary DR, Jacobs JW, Lu W, Lu Y, Sun J, Zhong M, Preparation of amino carboxamide derivatives as aspartyl protease inhibitors. 2003; Vol. WO 2003106405 , A1 20031224.

[45]. Mauser H, Nettekoven M, Schmitt S, Isophthalamide derivatives as BACE2 inhibitors and their preparation and use for the treatment of diabetes. 2012; Vol. US 20120053200 A1 20120301.

[46]. Ghosh AK, Kumaragurubaran N, Liu C, Devasamudram T, Lei H, Swanson L, Ankala S, Tang J, Bilcer G, Preparation of benzene-1,3-dicarboxamides which inhibit $\beta$-secretase activity. 2006; Vol. WO 2006110668 A1 20061019.

[47]. Green IR, October N, Arkivoc. 2010, 2, 71-96.

[48]. Sayyed IA, Sudalai A, Tetrahedron Asymm. 2004, 15, 3111-3116.

[49]. Prevost S, Gauthier S, de Andrade MCC, Mordant C, Touati AR, Lesot P, Savignac P, Ayad T, Phansavath P, Ratovelomanana-Vidal V, Genet JP, Tetrahedron Asymm. 2010, 21, 1436-1446.

[50]. Maillaird M, Hom C, Gailunas A, Jagodzinska B, Fang LY, John V, Freskos JN, Pulley SR, Beck JP, Tenbrink RE, Preparation of substituted amines to treat Alzheimer's disease. 2002; Vol. WO 2002002512 A2 20020110. 
[51]. Ghosh AK, Brindisi M, Nyalapatla PR, Takayama J, Ella-Menye JR, Yashchuk S, Agniswamy J, Wang YF, Aoki M, Amano M, Weber IT, Mitsuya H, Bioorg. Med. Chem 2017, 25, 5114-5127. [PubMed: 28434781]

[52]. Skelin M, Rupnik M, Cencic A, ALTEX 2010, 27, 105-113. [PubMed: 20686743]

[53]. Ishihara H, Asano T, Tsukuda K, Katagiri H, Inukai K, Anai M, Kikuchi M, Yazaki Y, Miyazaki JI, Oka Y, Diabetologia 1993, 36, 1139-1145. [PubMed: 8270128]

54. [] Rochin L, Hurbain I, Serneels L, Fort C, Watt B, Leblanc P, Marks MS, De Strooper B, Raposo G, van Niel G, Proc. Natl. Acad. Sci. U. S. A. 2013, 110, 10658-10663. [PubMed: 23754390] 

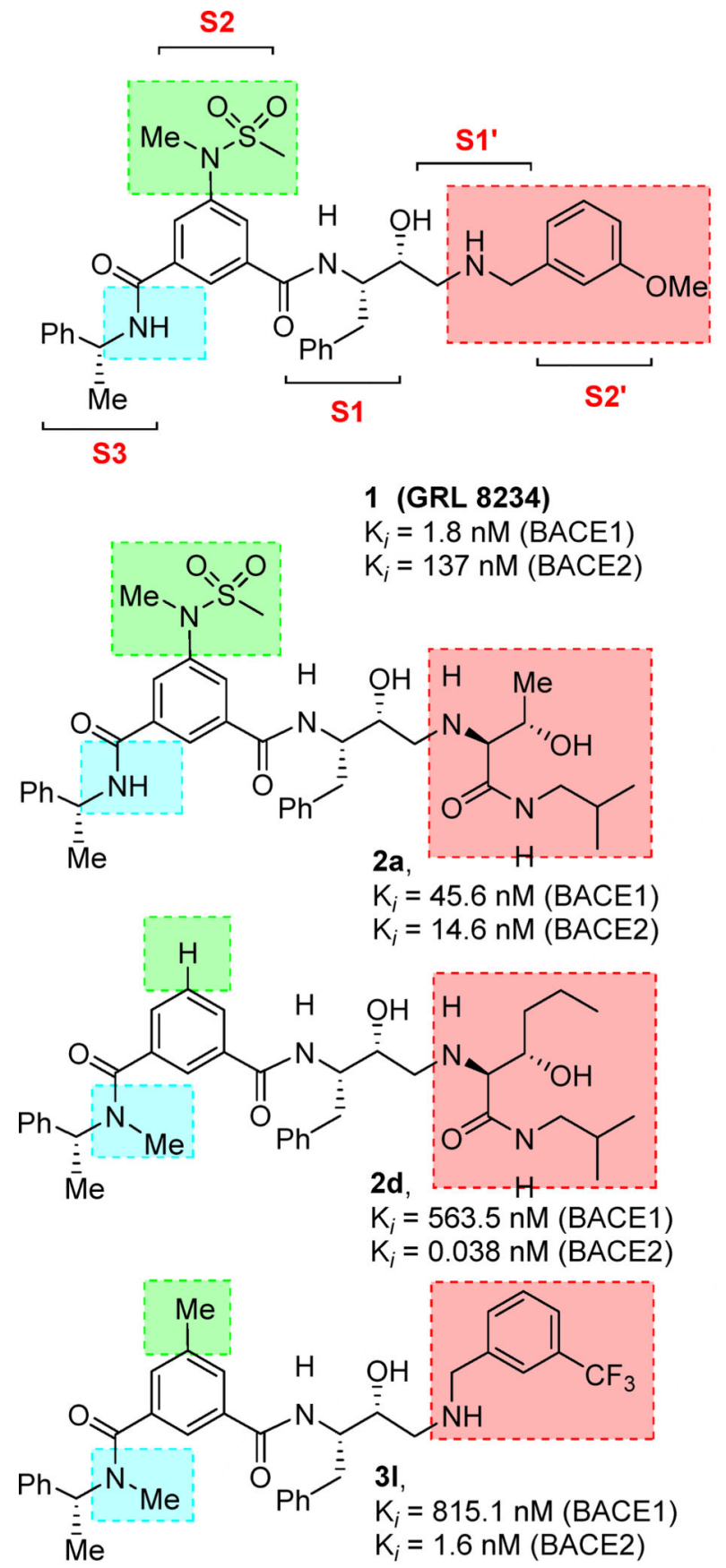

Figure 1.

Structures of BACE2 inhibitors 1, 2a, 2d and $\mathbf{3 1}$. 
A

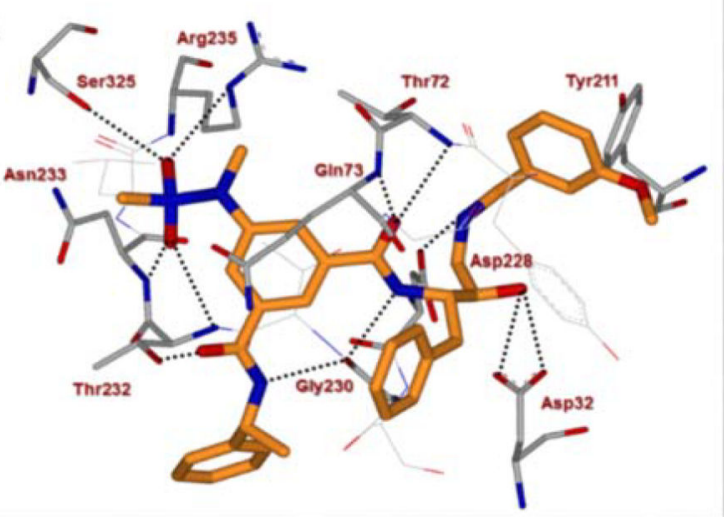

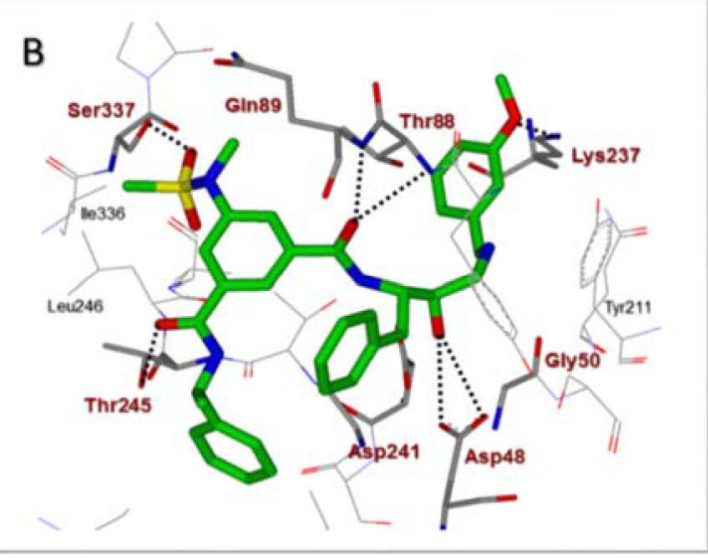

Figure 2.

(A) X-ray structure of inhibitor $\mathbf{1}$ (carbon chain, orange) bound to BACE1 (PDB code: $2 \mathrm{VKM}$ ). (B) An energy-minimized model of inhibitor $\mathbf{1}$ (carbon chain, green) bound in the BACE2 active site. All strong hydrogen bonding interactions are shown as dotted lines. The docking was performed with AutoDock Vina (see Supplementary Material for details). 

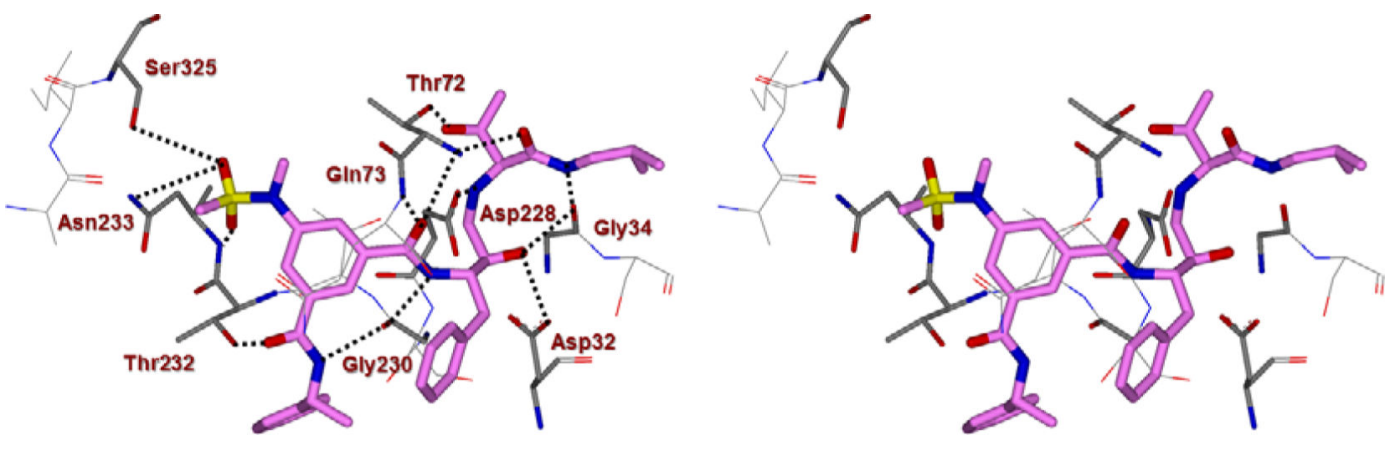

Figure 3.

A Stereoview of the X-ray structure of inhibitor 2a (carbon chain, magenta color) in complex with BACE1 (memapsin 2) (PDB code: 5DQC). All strong hydrogen bonding interactions are shown as dotted lines. 

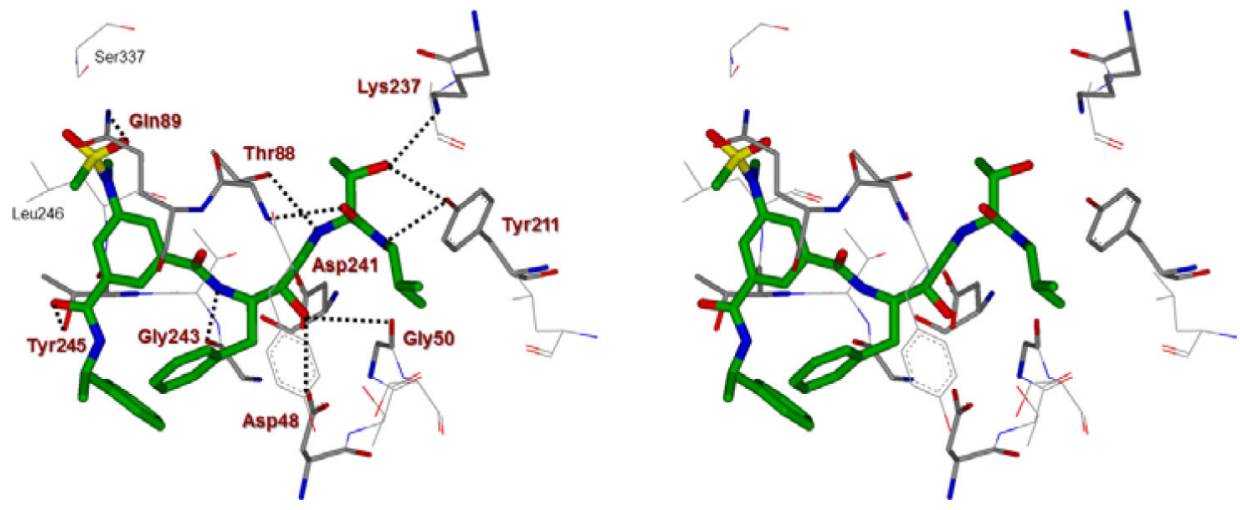

Figure 4.

A stereoview of an energy-minimized model of $\mathbf{2 a}$ (carbon chain, green) bound within the BACE2 active site. All strong hydrogen bonding interactions are shown as dotted lines. The docking was performed with AutoDock Vina (see SupplementaryInformation for details). 


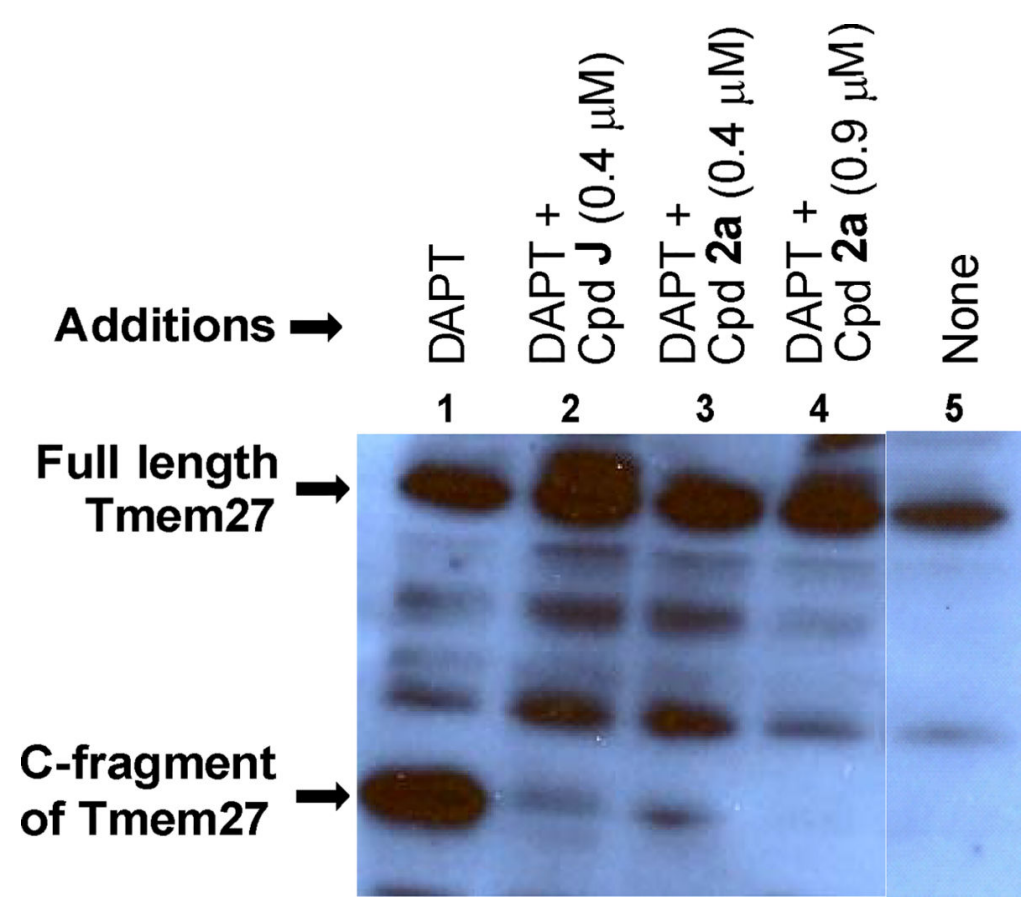

Figure 5.

Inhibition of BACE2 processing of Tmem27 by CpdJ and compound 2a (at two different concentrations) in MIN6 cells. Lanes 1 and 5 represent vehicle (DMSO) controls with and without DAPT, respectively. 


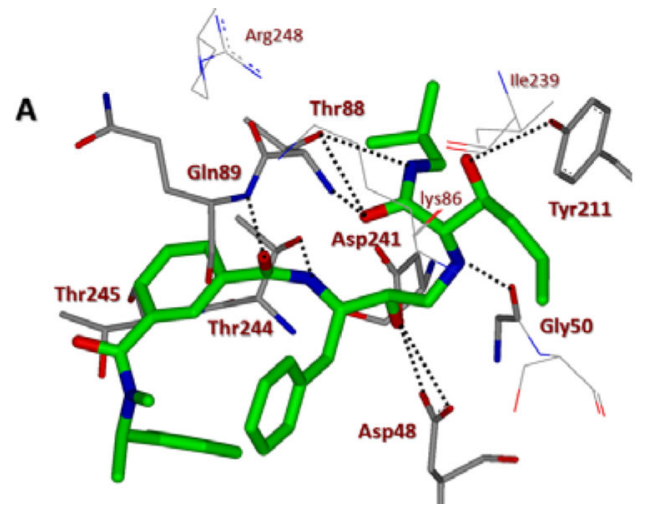

B

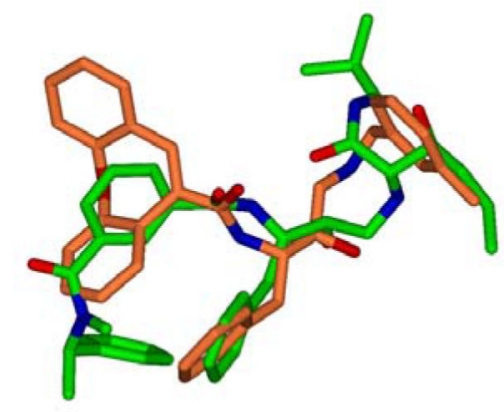

Figure 6.

(A) An energy-minimized model of inhibitor $\mathbf{2 d}$ (carbon chain, green) bound in the BACE2 active site. All strong hydrogen bonding interactions are shown as dotted lines. (B) Overlay of inhibitor $\mathbf{2 d}$ model with the X-ray crystal structure of hydroxyethylamine transition state inhibitor (carbon chain, orange) in BACE2 active site (PDB : 2EWY). The docking was performed with AutoDock Vina (see SupplementaryInformation for details). 

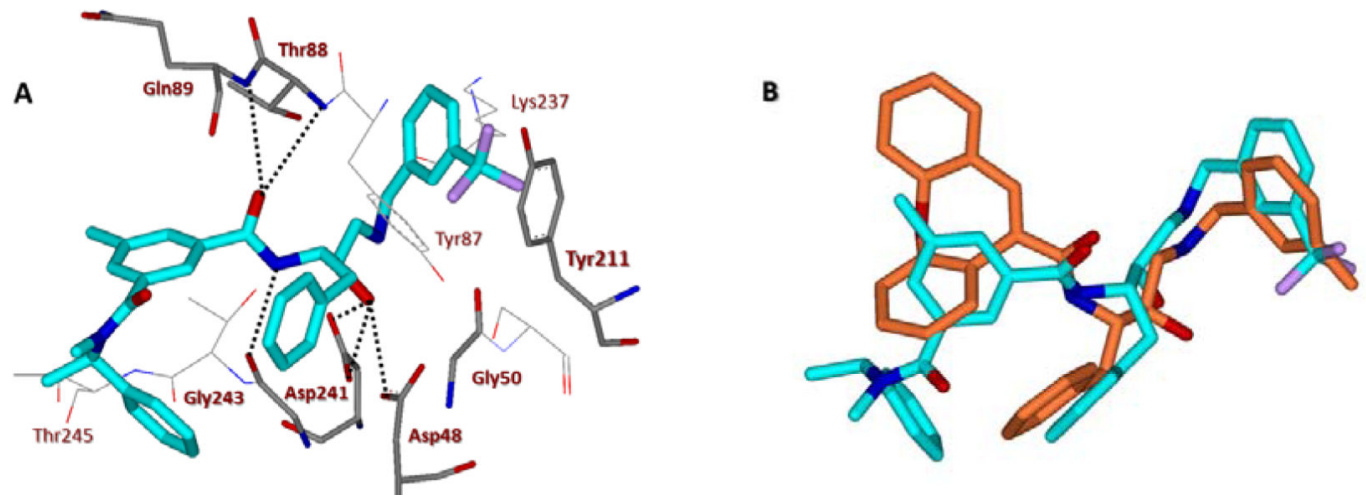

Figure 7.

(A) An energy-minimized model of inhibitor $\mathbf{3 l}$ (carbon chain, turquoise) bound in the BACE2 active site. All strong hydrogen bonding interactions are shown as dotted lines. (B) Overlay of inhibitor $\mathbf{3 l}$ model with the X-ray crystal structure of hydroxyethylamine transition state inhibitor (carbon chain, orange) in BACE2 active site (PDB : 2EWY). The docking was performed with AutoDock Vina (see SupplementaryInformation for details). 
<smiles>[R]c1cc(C(=O)O)cc(C(=O)N([R])[C@H](C)c2ccccc2)c1</smiles><smiles>[R]c1cc(C(=O)O)cc(C(=O)N2CCC[C@H]2COC)c1</smiles>

4a, $R^{1}=M e ; R^{2}=H$

5a, $\mathrm{R}^{2}=\mathrm{H}$

4b, $R^{1}=M e ; R^{2}=M e$

5b, $R^{2}=M e$

4c, $\mathrm{R}^{1}=\mathrm{Me} ; \mathrm{R}^{2}=\mathrm{N}(\mathrm{Me}) \mathrm{SO}_{2} \mathrm{Me}$

4d, $\mathrm{R}^{1}=\mathrm{H} ; \mathrm{R}^{2}=\mathrm{N}(\mathrm{Me}) \mathrm{SO}_{2} \mathrm{Me}$

4e, $\mathrm{R}^{1}=\mathrm{H} ; \mathrm{R}^{2}=\mathrm{Me}$<smiles>[R]c1cc(C(=O)O)cc(C(=O)N(C)Cc2nc(C)cs2)c1</smiles><smiles>[R]c1cc(C(=O)O)cc(C(=O)N(C)Cc2nc(C)co2)c1</smiles>

6a, $\mathrm{R}^{2}=\mathrm{H}$

$7 a, R^{2}=H$

6b, $R^{2}=M e$

$7 b, R^{2}=M e$

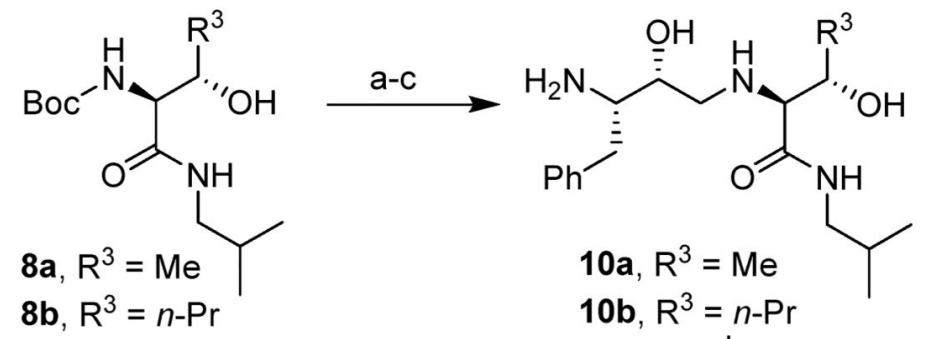

$\mathbf{8 b}, \mathrm{R}^{3}=n-\mathrm{Pr}$

10b, $\mathrm{R}^{3}=n-\mathrm{Pr}$<smiles>[R]c1cc(C(=O)N[C@H](CPc2ccccc2)[C@H](O)CN[C@H](C(=O)NCC(C)C)[C@H]([R3])O)cc(C(=O)N2CCCCCC2)c1</smiles>

Scheme 1.

Reagents and conditions (a) TFA, dry $\mathrm{CH}_{2} \mathrm{Cl}_{2}, 1 \mathrm{~h}$, from $0{ }^{\circ} \mathrm{C}$ to $25^{\circ} \mathrm{C}$; (b). $9, \boldsymbol{i}$-PrOH, $80{ }^{\circ} \mathrm{C}, 18 \mathrm{~h}$; (c) TFA, dry $\mathrm{CH}_{2} \mathrm{Cl}_{2}, 1 \mathrm{~h}$, from $0{ }^{\circ} \mathrm{C}$ to $25^{\circ} \mathrm{C}, 66-86 \%$ (3 steps) (d) Suitable acids $\mathbf{5 a}, \mathbf{b}$ and $\mathbf{6 a}, \mathbf{b}$ and appropriate amines $\mathbf{1 0 a}$ or $\mathbf{1 0 b}, \mathrm{EDCI} \cdot \mathrm{HCl}, \mathrm{HOBt} \cdot \mathrm{H}_{2} \mathrm{O}$, DIPEA, dry $\mathrm{CH}_{2} \mathrm{Cl}_{2}, 15 \mathrm{~h}, \mathrm{rt}, 39-78 \%$. 
<smiles>[R]c1cccc(C=O)c1</smiles>

11a, $\mathrm{R}^{1}=\mathrm{OMe}$ 11b, $R^{1}=H$

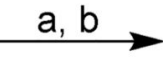

12a, $R^{1}=$ OMe, $R^{2}=M e$

12b, $\mathrm{R}^{1}=\mathrm{OMe}, \mathrm{R}^{2}=n-\mathrm{Pr}$

12c, $\mathrm{R}^{1}=\mathrm{H}, \mathrm{R}^{2}=n-\mathrm{Pr}$<smiles>[R]c1cccc([C@H]2OCCS(=O)C[C@H]2CCC)c1</smiles><smiles>[R]c1cccc([C@@H](O)[C@H]([R2])O)c1</smiles>

14a, $\mathrm{R}^{1}=\mathrm{OMe}, \mathrm{R}^{2}=\mathrm{Me}$

13a, $\mathrm{R}^{1}=\mathrm{OMe}, \mathrm{R}^{2}=\mathrm{Me}$

14b, $\mathrm{R}^{1}=\mathrm{OMe}, \mathrm{R}^{2}=n-\mathrm{Pr}$

13b, $\mathrm{R}^{1}=\mathrm{OMe}, \mathrm{R}^{2}=n-\mathrm{Pr}$

14c, $\mathrm{R}^{1}=\mathrm{H}, \mathrm{R}^{2}=n-\mathrm{Pr}$

13c, $\mathrm{R}^{1}=\mathrm{H}, \mathrm{R}^{2}=n-\mathrm{Pr}$

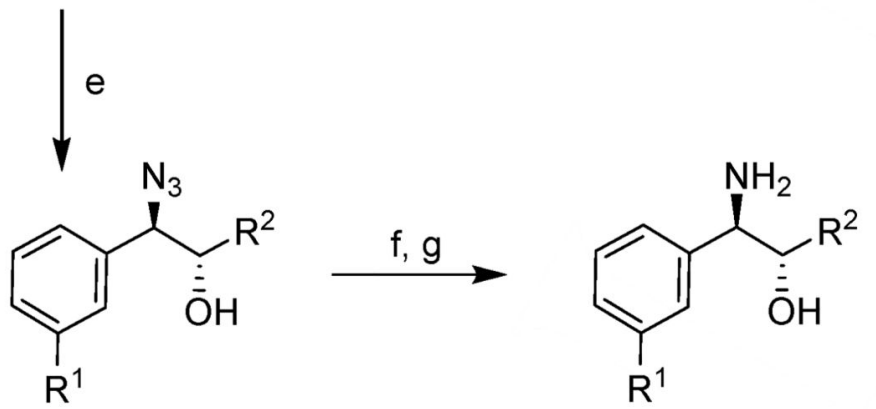

15a, $R^{1}=O M e, R^{2}=M e$

16a, $R^{1}=O M e, R^{2}=M e$

15b, $\mathrm{R}^{1}=\mathrm{OMe}, \mathrm{R}^{2}=n-\mathrm{Pr}$

$16 \mathrm{~b}, \mathrm{R}^{1}=\mathrm{OMe}, \mathrm{R}^{2}=n-\mathrm{Pr}$

15c, $\mathrm{R}^{1}=\mathrm{H}, \mathrm{R}^{2}=n-\mathrm{Pr}$

16c, $\mathrm{R}^{1}=\mathrm{H}, \mathrm{R}^{2}=n-\mathrm{Pr}$

Scheme 2.

Reagents and conditions. a) $\mathrm{R}^{2} \mathrm{CH}_{2} \mathrm{P}+\mathrm{Ph}_{3} \mathrm{Br}^{-}, \boldsymbol{n B u L i}$, dry THF, $1 \mathrm{~h},-78{ }^{\circ} \mathrm{C}$; b) $\left(\mathrm{CH}_{3} \mathrm{CN}\right)_{2} \mathrm{Cl}_{2} \mathrm{Pd}, \mathrm{CHCl}_{3}, 72 \mathrm{~h}, 25^{\circ} \mathrm{C}, 69-84 \%$ (2 steps); c) AD-mix-a $\boldsymbol{t}$ - $\mathrm{BuOH} / \mathrm{H}_{2} 0,24 \mathrm{~h}$, $25{ }^{\circ} \mathrm{C}, 68-73 \%$; d) TEA, thionyl chloride, $0{ }^{\circ} \mathrm{C}, 45 \mathrm{~min}, 66-79 \%$; e) $\mathrm{NaN}_{3}$, DMF, $10 \mathrm{~h}$, $80{ }^{\circ} \mathrm{C}, 74-88 \%$; f) (Boc) ${ }_{2} \mathrm{O}, \mathrm{H}_{2}, \mathrm{Pd} / \mathrm{C}$, EtOAc, $1 \mathrm{~atm}, 25^{\circ} \mathrm{C}, 15 \mathrm{~h}$; g) TFA, dry $\mathrm{CH}_{2} \mathrm{Cl}_{2}, 1 \mathrm{~h}$, from $0{ }^{\circ} \mathrm{C}$ to $25^{\circ} \mathrm{C}, 66-86 \%$ (2 steps). 


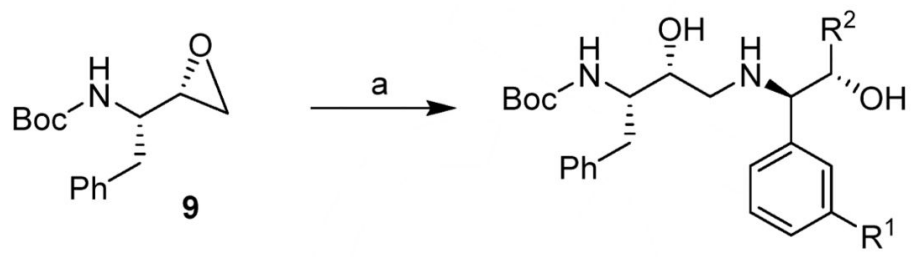<smiles>[R]c1cccc(C(N)C([R])O)c1</smiles>

$17 a, R^{1}=O M e, R^{2}=M e$

$17 \mathrm{~b}, \mathrm{R}^{1}=\mathrm{OMe}, \mathrm{R}^{2}=n-\mathrm{Pr}$

17c, $\mathrm{R}^{1}=\mathrm{H}, \mathrm{R}^{2}=n-\mathrm{Pr}$

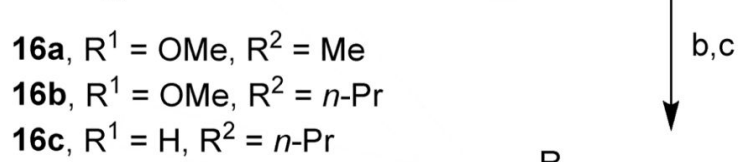

$16 \mathrm{c}, \mathrm{R}^{1}=\mathrm{H}, \mathrm{R}^{2}=n-\mathrm{Pr}$<smiles>[R]c1cc(C(=O)N[C@@H](Cc2ccccc2)[C@@H](O)CN[C@@H](c2cccc([R])c2)[C@@H]([R2])O)cc(C(=O)N(C)[C@@H](C)c2ccccc2)c1</smiles>

Scheme 3.

Reagents and conditions, a) $\mathbf{1 6 a}, \mathbf{1 6 b}$ or $\mathbf{1 6 c}, \boldsymbol{i}-\mathrm{PrOH}, 18 \mathrm{~h}, 80^{\circ} \mathrm{C}, 65-71 \%$; b) TFA, dry $\mathrm{CH}_{2} \mathrm{Cl}_{2}, 2 \mathrm{~h}$, from $0{ }^{\circ} \mathrm{C}$ to $25^{\circ} \mathrm{C}$; c) Acids $4 \mathbf{a}-\mathbf{d}$, EDCI $\cdot \mathrm{HCl}, \mathrm{HOBt} \cdot \mathrm{H}_{2} \mathrm{O}$, DIPEA, dry $\mathrm{CH}_{2} \mathrm{Cl}_{2}, 15 \mathrm{~h}, 25^{\circ} \mathrm{C}, 55-71 \%$ (2 steps). 


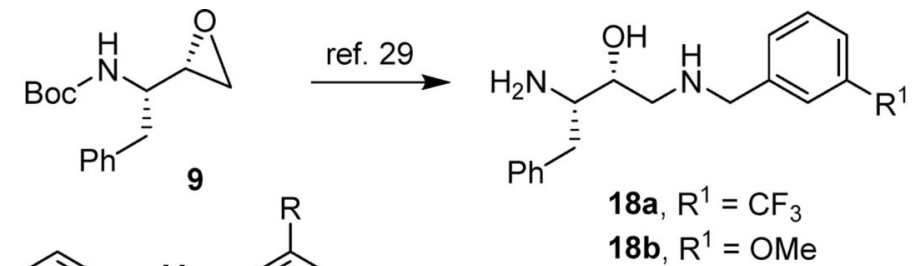<smiles>C[C@@H](c1ccccc1)N(C)C(=O)c1cc(I)cc(C(=O)O)c1</smiles>

$18 b, R^{1}=O M e$

4a, $\mathrm{R}=\mathrm{H}$

4b, $\mathrm{R}=\mathrm{Me}$<smiles>[R]Oc1cc(C(=O)O)cc(C(=O)N(C)Cc2nc(C)co2)c1</smiles>

$7 \mathrm{~b}, \mathrm{R}=\mathrm{Me}$<smiles>[R]c1cccc(CNC[C@H](O)[C@H](Cc2ccccc2)NC(=O)c2cc([R])cc(C(=O)N(C)[C@H](C)c3ccccc3)c2)c1</smiles>

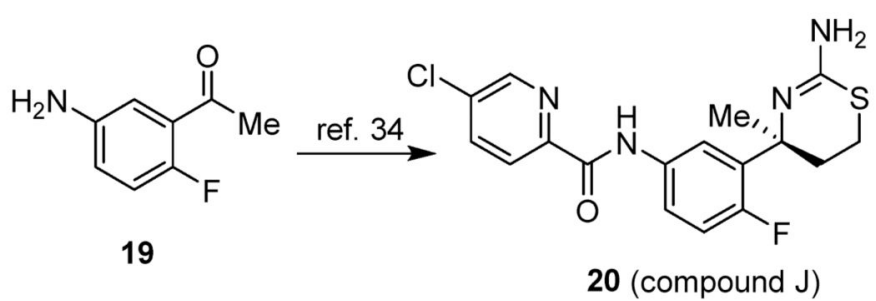

Scheme 4.

Reagents and conditions, a) Acids $\mathbf{4 a}, \mathbf{4 b}, \mathbf{7} \mathbf{a}$ or $\mathbf{7 b}$, EDCI·HCl, $\mathrm{HOB} \cdot \mathrm{tH}_{2} \mathrm{O}$, DIPEA, dry $\mathrm{CH}_{2} \mathrm{Cl}_{2}, 15 \mathrm{~h}, 25^{\circ} \mathrm{C}, 55-71 \%$ (2 steps). 
$\mathrm{Me}$<smiles>Cc1coc(CN(C)S(C)(=O)=O)n1</smiles><smiles>CC(=O)c1cc(C)cc(C(=O)O)c1</smiles>

$22 \mathrm{Me}$

23<smiles>COc1cccc(CNC[C@H](O)[C@H](N)Cc2ccccc2)c1</smiles><smiles>Cc1cc(C(=O)O)cc(C(=O)N(C)C(C)c2nc(C)co2)c1</smiles>

30

Scheme 5.

Reagents and conditions, a) $s$-BuLi, TMEDA, $\mathrm{Et}_{2} \mathrm{O},-78{ }^{\circ} \mathrm{C}, 30 \mathrm{~min}$, then $\mathrm{Mel},-78{ }^{\circ} \mathrm{C}$ to $25^{\circ} \mathrm{C}, 8 \mathrm{~h}, 86 \%$; b) TFA: $\mathrm{CH}_{2} \mathrm{Cl}_{2}(3: 1), 25^{\circ} \mathrm{C}, 1 \mathrm{~h}$; c) 23, EDCI, HOBt, DIPEA, $\mathrm{CH}_{2} \mathrm{Cl}_{2}$, $0{ }^{\circ} \mathrm{C}$ to $25^{\circ} \mathrm{C}, 12 \mathrm{~h}, 66 \%$ (2 steps); d) $\mathrm{LiOH} \cdot \mathrm{H}_{2} \mathrm{O}, \mathrm{THF}: \mathrm{H}_{2} \mathrm{O}(2: 1), 25^{\circ} \mathrm{C}, 6 \mathrm{~h}, 88 \%$; e) $\mathbf{1 8 b}$, EDCI, HOBt, DIPEA, $\mathrm{CH}_{2} \mathrm{Cl}_{2}, 0{ }^{\circ} \mathrm{C}$ to $25^{\circ} \mathrm{C}, 12 \mathrm{~h}, 48 \%$. 
Table 1.

Structure and activity on BACE1 and BACE2 enzymes for title inhibitors $\mathbf{2 a}-\mathbf{j}$.

(n)

${ }^{a} K_{\mathrm{i}}$ values for BACE1 enzyme have been determined as described in ref. 36

$b_{K}$ values for BACE2 enzyme have been determined as described in ref. 36. 
Table 2.

Structure and activity on BACE1 and BACE2 enzymes for title inhibitors 3a-h.

\begin{tabular}{|c|c|c|}
\hline Inhibitor & $K_{\mathrm{i}}(\mathrm{nM})^{a}$ BACE1 & $K_{\mathrm{i}}(\mathrm{nM})^{b}$ BACE2 \\
\hline & 205.3 & 730.8 \\
\hline & 4852 & 479 \\
\hline & 51331 & 950 \\
\hline & 16229 & 480 \\
\hline & 38633 & 243 \\
\hline & 8805 & 141 \\
\hline & 42485 & 2552 \\
\hline & 18130 & 905 \\
\hline
\end{tabular}

${ }^{a} K_{\mathrm{i}}$ values for BACE1 enzyme have been determined as described in ref. 36

$b_{K \mathrm{i}}$ values for BACE2 enzyme have been determined as described in ref. 36. 
Table 3.

Structure and activity on BACE1 and BACE2 enzymes for title inhibitors 3i-o.

\begin{tabular}{|c|c|c|}
\hline Inhibitor & $K_{\mathrm{i}}(\mathrm{nM})^{a}$ BACE1 & $K_{\mathrm{i}}(\mathrm{nM})^{b}$ BACE2 \\
\hline & 2085 & 39.45 \\
\hline & 837 & 14.02 \\
\hline & 1347 & 35.71 \\
\hline & 815.1 & 1.6 \\
\hline & 68.8 & 7332 \\
\hline & 25.36 & 1921 \\
\hline & 767 & 801 \\
\hline
\end{tabular}

${ }^{a} K_{\mathrm{i}}$ values for BACE1 enzyme have been determined as described in ref. 36

$b_{K \mathrm{i}}$ values for BACE2 enzyme have been determined as described in ref. 36. 